\title{
Regional Distribution of Ambulant Nursing Services in Germany. A GIS Accessibility Analysis
}

\author{
Stefan Neumeier ${ }^{1}$
}

Received: 4 January 2016 / Accepted: 30 May 2016 / Published online: 30 June 2016

(c) Springer-Verlag Berlin Heidelberg 2016

\begin{abstract}
In many rural areas in Europe a spatial concentrating of basic services can be observed due to interacting socioeconomic and demographic processes. At the European level, territorial cohesion policy aims at mitigating the consequences of this development. Additionally, in Germany, this development is a greatly discussed topic. However, little data exists at the country level on the dimensions and consequences of this spatial concentration process. This limitation makes it difficult to realistically assess the situation and identify the regions and basic services where intervention may be required. As a contribution to bridging this knowledge gap, we used a GIS accessibility analysis to analyse the regional distribution of ambulant nursing services throughout Germany and to estimate the availability of such services near patients' places of residence. Ambulant nursing care is an important basic service of the German health care system; such services allow disabled or elderly people who are not able to fully care for themselves to stay in their homes and living environments. The analysis results lead us to conclude that although ambulant nursing services must cover greater distances to reach customers in rural areas, at present such services are nationally available in rural areas as well as in urban areas.
\end{abstract}

Keywords Rural development - Medicare · Ambulant nursing services as defined in the German Social Code Book XI · Raster-based GIS-accessibility analysis

Dr. Stefan Neumeier

stefan.neumeier@ti.bund.de

1 Federal Research Institute for Rural Areas, Forestry and Fisheries, Institute of Rural Studies, Johann Heinrich von Thünen-Institute, Bundesallee 50, 38116 Braunschweig, Germany

\section{Regionale Verteilung ambulanter Pflegedienste in Deutschland. Eine GIS-Erreichbarkeitsanalyse}

Zusammenfassung Gegenwärtig lässt sich in den ländlichen Räumen beobachten, dass sich wechselseitig beeinflussende sozioökonomische und demographische Prozesse zu einer räumlichen Konzentration von Daseinsvorsorgeinfrastrukturen führen. Das heißt: demographische Entwicklungen bedingen eine Veränderung der Nachfrage, was in Folge zur Aufgabe unrentabler Standorte führt. Auf europäischer Ebene versucht man dieser Entwicklung durch die Politik des Territorialen Zusammenhalts zu begegnen. Ein ähnliches Ziel verfolgt Deutschland seit 1965 mit dem im $\S 2$ des Raumordnungsgesetzes festgeschriebenen Ziel der Gewährleistung gleichwertiger Lebensbedingungen in allen Landesteilen. Vor diesem Hintergrund ist es überraschend, dass es bislang für Deutschland nicht in allen relevanten Bereichen, kleinräumige, flächendeckende Daten gibt, die Auskunft über das Ausmaß und die Folgen dieses Konzentrationsprozesses geben. Das führt dazu, dass es schwer ist, die Situation realistisch zu erfassen sowie Regionen und Infrastrukturen zu identifizieren, bei denen gegebenenfalls Interventionsbedarf besteht. Um einen Beitrag zum Abbau dieses Informationsdefizits zu leisten, haben wir mit Hilfe einer GIS-Erreichbarkeitsanalyse die regionale Verteilung ambulanter Pflegedienste in Deutschland, die Dienstleistungen gemäß SGB XI anbieten, analysiert. Die Ergebnisse der GIS-Analyse ermöglichen es, die wohnortnahe Verfügbarkeit ambulanter Pflegedienste nach SGB XI kleinräumig, unterhalb der Ebene der Gemeinden, abzuschätzen. Als wichtigstes Ergebnis lässt sich festhalten: Obwohl in ländlichen Regionen von ambulanten Pflegediensten weitere Wege zu den potenziellen Kunden zurückgelegt werden müssen, ist derzeit in Deutschland die grundlegende wohnortnahe Versorgung mit ambulanten Pflegediensten sowohl 
in ländlichen als auch städtischen Regionen flächendeckend gewährleistet.

Schlüsselwörter Entwicklung ländlicher Räume · Medizinische Versorgung - Ambulante Pflegedienste nach SGB XI · Rasterbasierte GIS-Erreichbarkeitsanalyse

\section{Introduction}

Throughout Europe, it can be observed that demographic trends that account for a changing demand for basic services (e.g. population decline, aging population) are exerting economic pressure on private and public service providers, which in turn leads to an abandonment of unprofitable locations (Higgs/White 1997: 444). Expressed in simplified terms, these shrinking processes could lead to a downwards spiral, whereby shrinking causes a decrease in attractiveness, which in turn leads to further shrinking (Specht/Wenz/ Häring et al. 2013: 9). At the European level, such processes are discussed within the scope of territorial cohesion policy, the main objective of which is an equal distribution of resources and services among the regions and their populations in order to ensure people sufficient access to basic services wherever they live (European Commission 2014: 3). Similarly, the German regional planning policy follows the objective of ensuring comparable living conditions in all regions of Germany within the context of Daseinsvorsorge, which was legally stipulated in 1965 in $\S 2$ of the Federal Regional Planning Act. Thereby, Daseinsvorsorge involves the public provision of a sufficient supply of the goods and services that are indispensable for life and cater for common welfare, as well as the appropriate access to these goods and services (Einig 2008; Burgdorf/Krischausky/MüllerKleißler 2015). Facilities that offer such goods and services are part of social infrastructure. It thus follows that analyses about the availability and accessibility of such facilities provide important data for political and scientific discourse on Daseinsvorsorge (Burgdorf/Krischausky/MüllerKleißler 2015), where the spatial concentration of basic services is currently a heavily debated issue (Schulz/Bröcker 2007; Neu 2009; Steinführer/Küpper/Tautz 2012; Slupina/ Sütterlin/Klingholz 2015)1.

Interestingly, within this German discourse the social dimension of sustainability, concentrating for example on (different) public needs, is masked because the main focus lies only on economic aspects, diverging from the aim

\footnotetext{
1 As the processes, consequences and reasons for the spatial concentration of basic services have already been intensively discussed elsewhere, the reader is directed to, for example, Favry 2006; Schmitz-Veltin 2006; Gawron 2008; Born 2009; Jens 2009; Neu 2009; BMVBS 2010; Küpper 2011; BMVBS 2013; Steinführer 2014; Steinführer/Küpper/ Tautz 2014 for further information on these aspects.
}

of sustainability (Küpper/Steinführer/Stelzenmüller et al. 2013: 7). This focus might in part result from the small amount of data existing at the county level due to the dimensions of the process, as well as the consequences that it has on citizens (Küpper/Eberhardt 2012: 6). Certainly, the nationwide availability of small-scale data on the accessibility of basic and local services is suboptimal (Burgdorf/Krischausky/Müller-Kleißler 2015: 3). The particular importance that legislature attaches to this aspect in $\S 2$ (3) Federal Regional Planning Act renders this lack of information dissatisfying (Burgdorf/Krischausky/MüllerKleißler 2015: 3).

Against this background, we began analysing the nationwide accessibility of selected basic services by modelling accessibility with the help of a Geographic Information System (GIS). Thus far, we have analysed street petrol station accessibility (Neumeier 2012), the accessibility of supermarkets and discounters (Neumeier 2014a) and the accessibility of public pharmacies (Neumeier 2013). Interestingly, the results are comparable for all the basic services analysed thus far. One can register a rural-urban divide as well as regional variations, but from a nationwide point of view the provision of these basic services is still guaranteed throughout the country. By addressing the basic availability of an ambulant nursing service near the place of residence, this paper continues these accessibility studies by adding another important basic service of the German health care system, one that allows disabled or elderly people who cannot fully care for themselves to stay in their homes and living environments - especially in rural areas where distances to the next physician are often comparatively long (Heit/Köppe/Kratschke et al. 2014: 141 f.). The paper addresses the availability of an ambulant nursing service that offers services according to SGB $\mathrm{XI}^{2}$ near the place of residence in Germany. Thereby, the basic availability situation is described using a "simple" generic accessibility indicator defined as the distance to the nearest ambulant nursing service derived by a shortest path network analysis. Thus, the analysis does not address the delineation of different possible catchment areas or different options available. Because the declared goal of the analysis is to obtain a nationwide picture of the situation, it was also not feasible to account for the real catchment areas, place of residence of the potential customers, number of employees or customers per employee of the nursing services. Such data are not available, due in part to data privacy laws that render it impossible to acquire such information on a national level.

The remainder of this article is divided into four sections. In Sect. 2, some introductory key information on ambulant nursing services in Germany is given. Sect. 3 describes the methodology of the GIS accessibility analysis. The results

\footnotetext{
2 SGB XI: German Social Code Book XI.
} 
are presented in Sect. 4. The paper closes with a summary of the main findings followed by some concluding remarks.

\section{Key Information on Ambulant Nursing Services}

In Germany, since 2003, a steady increase can be registered in the number of ambulant nursing services that offer services according to SGB XI. In other words, these are nursing services that are covered by the German statutory health insurance. Whereas 10,598 ambulant nursing services existed in Germany in 2001, the number of service providers had increased to 12,349 by 2011 (Statistisches Bundesamt 2013a: 6$)^{3}$, and according to the nursing-service-navigator of the AOK (a German public health insurance company), to 13,466 by 2014 (http://www.aok-pflegedienstnavigator.de/ index.php? module $=$ careservice, a website that publishes the current locations and number of service providers). According to figures from 2011, $62.9 \%$ of the ambulant nursing services are privately owned, caring for $48.6 \%$ of people in need of care, $35.7 \%$ are charitable organizations caring for $49.8 \%$ of those in need of care, and $1.4 \%$ are public sector institutions caring for $1.6 \%$ of people in need of care (Statistisches Bundesamt 2013a: 6). On average in Germany, the 2011 figures show that an ambulant nursing service serves 47 people who are in need of care (Statistisches Bundesamt 2013a: 6).

Overall, in 2011, 290,714 persons were employed in ambulant nursing services. On average, an ambulant nursing service employs 23.5 employees. Thereby, it is striking that in $2011,88 \%$ of the employees of ambulant nursing services were female, and $70 \%$ were employed part-time. It is interesting that in the new federal states (former German Democratic Republic), in 2011, the share of people working full time was between $35 \%$ and $43 \%$, which is higher than that in the former federal states (Federal Republic of Germany until 03.10.1990) (Statistisches Bundesamt 2013a: 9-11).

In addition to services according to SGB XI, nearly all of the ambulant nursing services also offer services according to SGB Part V ${ }^{4}$ (domestic care for sick people) (Statistisches Bundesamt 2013b). Thus, ambulant nursing services offer services to people who are in need of a range of care, varying from simply helping with the intake of medication, to measuring blood pressure and blood sugar, to helping with personal hygiene. As such, they help to allow disabled or elderly people who cannot fully care for themselves to stay in their homes and living environments (Heit/Köppe/ Kratschke et al. 2014: 142).

\footnotetext{
3 The official nursing statistics used were published in 2013. These statistics show data for the reference year 2011.

4 SGB V: German Social Code Book V.
}

Nursing services are offered both as pre-defined service complexes and based on the time spent on the service. The defined service complexes offered by ambulant nursing services and the prices of the single complexes differ among the federal states (Hielscher/Nock/KirchenPeters et al. 2013). Depending on the federal state, travel expenses are included in the service complexes according to SGB XI or are listed as a separate complex. According to SGB V, service complexes can be charged as extras (Hielscher/Nock/Kirchen-Peters et al. 2013). In addition to the service complexes, since 2013 ambulant nursing services must also offer services based on time, to enable customers to better shape the services according to their specific personal needs. With payment according to service complexes, the longer and shorter tasks balance one another out. This compensation does not occur with payment according to time (Deutsches Medizinrechenzentrum 2013: $1)$.

Elderly people constitute the main group that is in need of nursing services (Statistische Ämter des Bundes und der Länder 2010). In Germany, in 2011, 2.5 million people were in need of care according to SGB XI; this amounts to $3.1 \%$ of the overall German population. Of those in need of care, $69 \%$ are older than 75 years of age (Statistisches Bundesamt 2013c: 6, 8). Of the 2.5 million people who are in need of care, $23 \%$ (i. e. $576,264 / 2,501,441$ ) make use of ambulant nursing services according to SGB XI (Statistisches Bundesamt 2013a: 8, Statistisches Bundesamt 2013c: 6). People who are in need of care are free to choose an ambulant nursing service, but they must cover the additional costs if the service chosen does not normally serve the place of residence. The share of people who are in need of care varies among the federal states (see Table 1). In 2011, the highest share of those in need of care was registered in Mecklenburg-West Pomerania (4.1\%), followed by Brandenburg (3.9\%). The lowest share was registered in Baden-Württemberg (2.6\%), followed by Bavaria (2.6\%) (Statistisches Bundesamt 2013c: 8).

According to the 12th coordinated population projection of the Federal Statistical Office of Germany, in the next few years the number of those aged 60 years and over is going to increase. According to the model, with regard to the lower limit of the population projection, "in 2030 there will be 7.3 million more people aged 60 years and older (28.5 million) in Germany than in 2009 (21.2 million)" (Statistische Ämter des Bundes und der Länder 2010: 5, own translation). This change allows us to reason that the share of people who are in need of care is also going to increase in the future, especially in regions where a considerable increase in the number of elderly people is expected.

According to a population projection of the Federal Institute for Research on Buildings, Urban Affairs and Spatial Development (BBSR), the share of people who are 80 years 


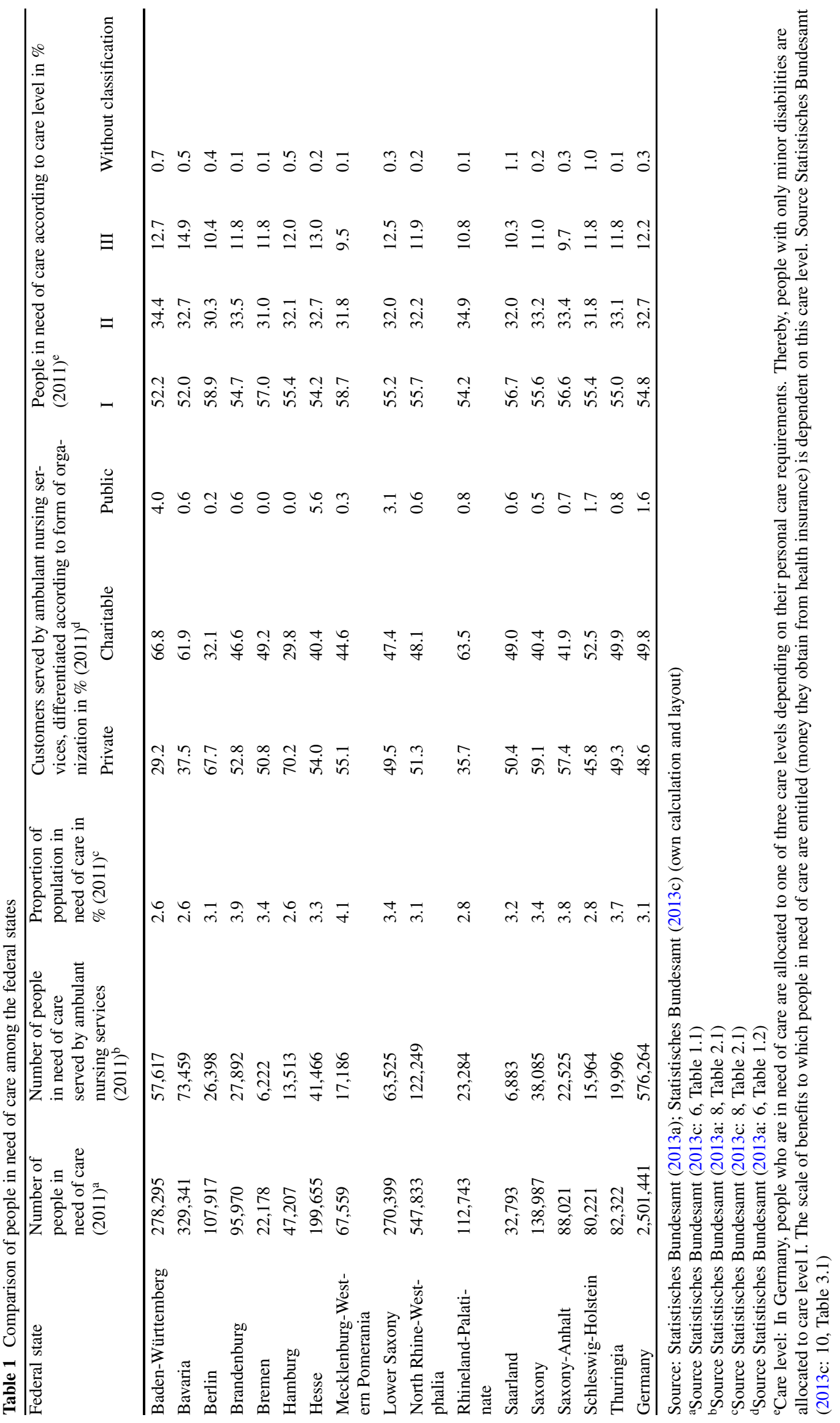


and older is also going to increase until 2035, especially in the federal states of Mecklenburg-Western Pomerania, Brandenburg, Schleswig-Holstein and in the north of Lower Saxony and widespread parts of Baden-Württemberg and Bavaria. Thus, especially in these regions, a further increase in people in need of care can be expected in the future (BBSR 2015).

\section{Method: GIS Accessibility Analysis}

\subsection{Accessibility Indicators - Theoretical Background}

Accessibility indicators measure the benefit that accrues from the available transport infrastructures, e. g. road systems (Bleisch/Koellreuter 2003: 7). They can be simple supply indicators (e.g. length of road network, number of supermarkets per community) or more complex generic indicators (e.g. travel times). The different methods used to acquire accessibility indicators can be roughly divided into the following three categories: (a) approaches common in transport sciences that are based on a prognosis of the traffic situation (e.g. gravitation models, opportunity models, random utility theory) (Bleisch 2005; Schulz/ Bröcker 2007), (b) approaches that capture the characteristics of the regional economy in spatial interaction models (gravitation models, logit-models) (Bleisch 2005; Schulz/ Bröcker 2007) and (c) approaches that focus on geographic accessibility (Euclidean distance, distance within street networks) (Hemetsberger/Ortner 2008). The analysis of the availability of ambulant nursing services near the place of residence is based on the geographic accessibility approach of analysing distances within street networks. This approach is used because determining driving distances in street networks best reflects reality with regard to the mobility behaviour of ambulant nursing services. Although the determination of street distances is more cost-intensive than the determination of Euclidean distances, a conscious decision was made in favour of street distances. This is based on the fact that although the Euclidean distance provides sufficiently accurate results in regions that have a dense road network, such as urban areas, the performance of this method is poor in regions that have sparse road networks, such as rural areas. Here, the circumvention of anthropogenic and natural barriers is more likely to considerably extend the distances to be covered and is expected to exceed that of Euclidean distances (Dahlgren 2008: 16).

\subsection{Accessibility Approach Applied}

In regional distance analyses, it is quite common to determine the distance from the centroid of an administrative unit to the service of interest and to assign the determined distance as the distance value of the administrative unit. This approach is quite straight-forward, but it also poses some problems because of the modifiable areal unit problem (MAUP). These considerations mean that the intraregional differences are masked (for details, see for example Madelin/Frasland/Mathian et al. 2009). We therefore decided to base our analysis on the so-called raster-based approach. This implies that the area under consideration (Germany) is overlaid by a vector raster (grid) that has a specific cell size. These raster cells represent the analysis regions. The centroids of the single raster cells represent the destinations of the analysis, which means that the shortest street distance from every centroid to the next origin (the location of ambulant nursing services) is determined. The resulting distance value is attributed to the raster cell representation of the distance of this cell. The within-cell distances are not considered. As such, the cell size of the analysis raster determines the accuracy of the accessibility model. The smaller the cell size is, the more accurate the model. Simultaneously, the smaller the cell size is, the larger the amount of computational cost necessary. Nevertheless, one advantage of the raster approach is that, based on the single raster cells, the indicator values of interest for administrative units can easily be obtained, for example by computing the arithmetic mean of the values that are attributed to raster cells covering an area of interest. Accordingly, a raster-based statistical approach allows accessibility to be analysed below the level of the administrative regions or census regions 5 .

\subsection{Data Sources}

For cost benefit purposes, it was decided to base the analysis on the street network of the ATKIS Basis DLM ${ }^{6}$, which is an official topographic cartographic information system for Germany. The so-called EWZ 250 was used as the raster of reference; it is compliant with the European INSPIREgrid (Infrastructure for Spatial Information in the European Community), covers the whole of Germany and was developed by the Federal Institute for Research on Building, Urban Affairs and Spatial Development (Burgdorf 2010) 7 . This raster has a cell size of $250 \mathrm{~m}$ and contains disaggregated population values based on official population statistics $^{8}$ as well as the population data of urban districts

\footnotetext{
5 A detailed introduction to the nature of raster-based regional statistics is given by Kaup/Rieffel (2013).

${ }^{6}$ Amtliches Topographisch-Kartographisches Informationssystem.

7 The EWZ 250 is not publicly available and was provided by the Federal Institute for Research on Building, Urban Affairs and Spatial Development upon request.

${ }^{8}$ Unfortunately, Burgdorf (2010) does not specify the year of reference for the population values that the disaggregation is based on. Considering that in the references he lists a "Qualitätsbericht - Fort-
} 
Table 2 Statistical parameters that describe the values of the distribution of the accessibility analysis

\begin{tabular}{lll}
\hline Indicators & $\begin{array}{l}\text { Potential outliers } \\
\text { are not corrected } \\
\text { (Values are rounded to full numbers) }\end{array}$ & $\begin{array}{l}\text { Potential outliers } \\
\text { are corrected }\end{array}$ \\
\hline Minimum in meters & 9 & 9 \\
Maximum in meters & 129,915 & 33,619 \\
1. Quartile in meters & 1,992 & 1,992 \\
3. Quartile in meters & 6,865 & 6,864 \\
Median in meters & 4,149 & 4,149 \\
Mean in meters & 4,873 & 4,836 \\
Standard error of mean & 3 & 3 \\
in meters & & 3,528 \\
Standard deviation in & 3,913 & \\
meters & & $12,448,524$ \\
Variance in meters & $15,307,525$ &
\end{tabular}

for raster cells that were identified as inhabited based on the ATKIS Basis DLM. Inherent to the distribution of the population over the raster cells is that in urban areas the population is to some extent underestimated, whereas in rural areas it is to some extent overestimated (more detailed information on these aspects can be found in Burgdorf 2010). This, combined with the fact that the EWZ 250 shows population data for 2008 , means that the population data based on the EWZ 250 should be considered as indicative only. With regard to the accessibility analysis, only raster cells that were identified as inhabited were considered, in order to reduce the computation costs. Overall, the raster of reference contains 1,667,191 raster cells. The locations of the ambulant nursing services are based on the nursingservice-navigator of the Federation of the German AOKs (German public health insurance companies). According to the Federation of the German AOKs the nursing-servicenavigator contains data updated daily. For the purpose of the analysis the Federation of the German AOKs provided us with locational information on 13,466 locations of ambulant nursing services as of 2 June 2014. Thus, the data set contains 1,117 locations more than those listed in the official nursing statistics published in 2013, which are based on 2011 data. As the official statistics publish the nursing data with a considerable time-lag, the AOK data set could not be verified with regard to the number of service locations contained.

\footnotetext{
schreibung des Bevölkerungsstandes" by the Federal Statistical Office from 2008, it can be assumed that the population data used for the disaggregation is also based on the population as of 2008. The calculation of a statistical population raster is a project in its own right, as the population must be reliably disaggregated from administrative units to raster cells using additional data sets, such as remote sensing data on the built environment, data on housing types and land use. As such, within the scope of this analysis it was not feasible to construct a more up-to-date data set for Germany, containing population data of 2014.
}

\subsection{Methods for Accessibility and Data Validation}

Methodically, the accessibility analysis is based on a GIS network analysis using the "a-star shortest path" algorithm (Hart/Nielsson/Raphael 1968), and was performed with PostgreSQL and the Postgis and pgRouting extensions. Both the raster centroids and the locations of the ambulant nursing services were connected with the road network prior to the accessibility analysis. Overall, the accessibility analysis is implicitly based on the simplified assumption that the closest destinations (raster cells) according to the street distance are served from each origin (ambulant nursing service). Because of the available computer capacities, it was not feasible to determine all of the possible $22,450,394,006$ origin-destination combinations. Thus, in a first step for every destination, the closest three origins were selected by considering the Euclidean distances. In a second step, the street distances from the destination to the origins were determined. The origin with the lowest determined distance was then finally attributed to the destination under consideration. For $0.92 \%$ of the raster cells, no street distances could be determined because of topological inconsistencies in the route network (mainly the existence of subgraphs $)^{9}$ that could not be corrected prior to the analysis without performing undesirable alterations to the topology of the overall network.

To compensate for these missing values, Euclidean distances were taken for the cells affected instead. To account for potential outliers, origin-destination pairs with extreme distance values (distance values above the upper quartile of the value distribution plus the triple interquartile distance) were recalculated by considering the closest 20 origins and finally choosing the origin-destination pair with the shortest street distance. This potential outlier correction was applied to 3,106 $(0.19 \%)$ calculated distances. Table 2 and Fig. 1 give a summary of the non-outlier-corrected and outlier-corrected value distributions of the accessibility analysis. The shape of the non-outlier-corrected and outliercorrected distribution of the calculated accessibility values is depicted in the two histograms at the top of Fig. 1. As can be seen by comparing the two histograms, the number of extreme distance values $(>20,000 \mathrm{~m})$ could be reduced (corrected) by the outlier analysis. The same aspect is shown in the two boxplots at the bottom of Fig. 1 from a different perspective. The boxplots show the variability of both the non-outlier-corrected and outlier-corrected accessibility data set. Similar to the histograms, it can be seen that the outlier correction contributed to a reduction of the extreme distance values (depicted as black dots above the whisker of the upper quartile of the value distribution). As is made particularly clear by comparing the boxplots, the acquired very

\footnotetext{
${ }^{9}$ For details see Neumeier (2015).
} 


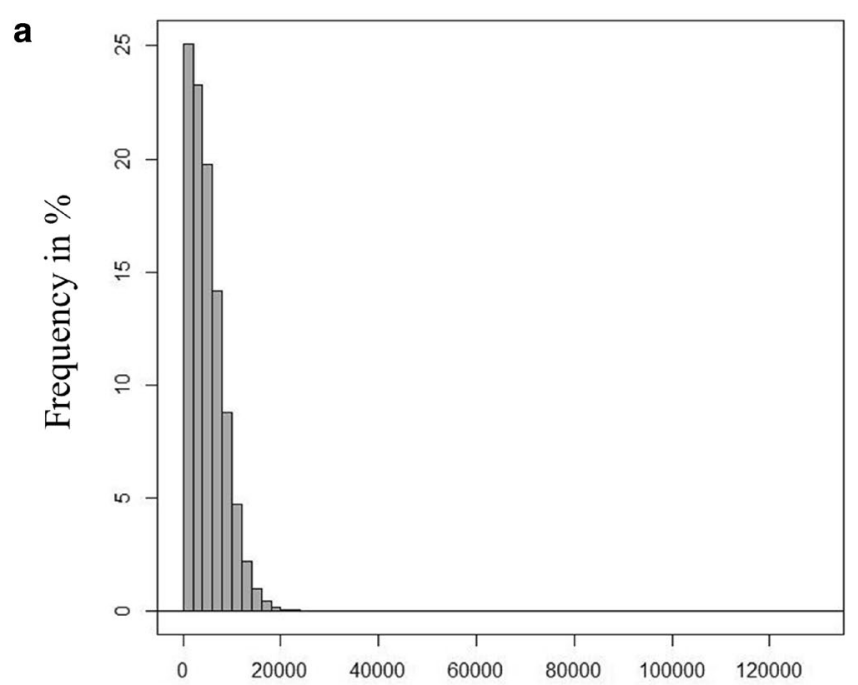

Distance to the next ambulant nursing service

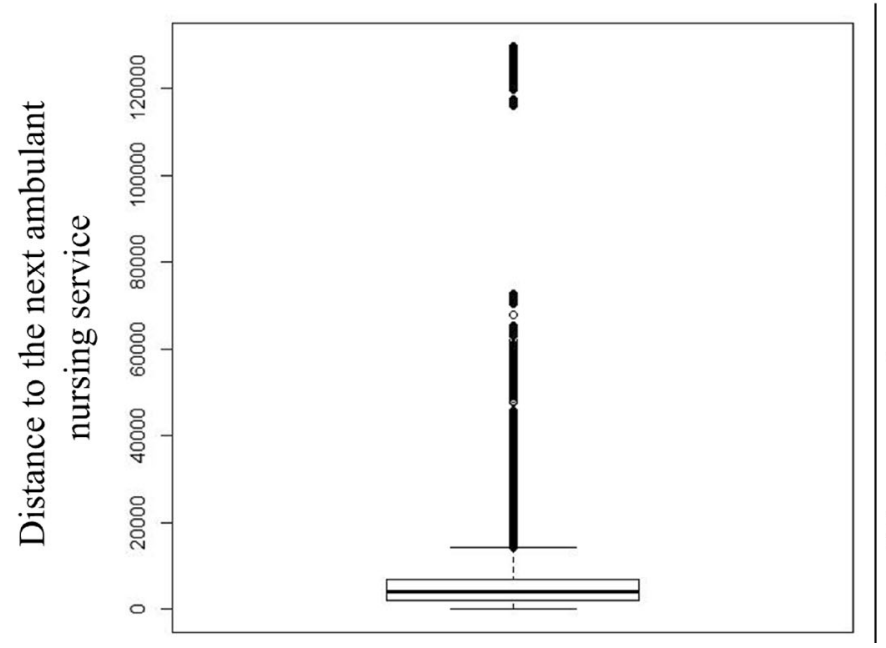

Fig. 1 Histogram and box plot of the value distribution of the accessibility analysis. The left outliers (a) are not corrected; the right outliers (b) are corrected

extreme distances ( $>20,000 \mathrm{~m}$ and especially $>80,000 \mathrm{~m}$ ) could be corrected by the outlier correction procedure.

To assess the quality of the accessibility model, it was decided to validate the model via reference data. One possibility to perform the validation is to compare the distances of randomly selected origin-destination pairs calculated by the accessibility model with those calculated by a webbased routing application.

In practice, this step is not as easy as it initially appears for the following reasons: a) the quality of the distance calculation is dependent on the quality of the street network that underlies the routing application - here, proprietary services usually perform better than Open Source services (for details, see Neumeier 2014b); b) proprietary services often do not allow the results that are obtained to be used for building one's own databases, which disqualifies them as a reference service; c) different routing applications use
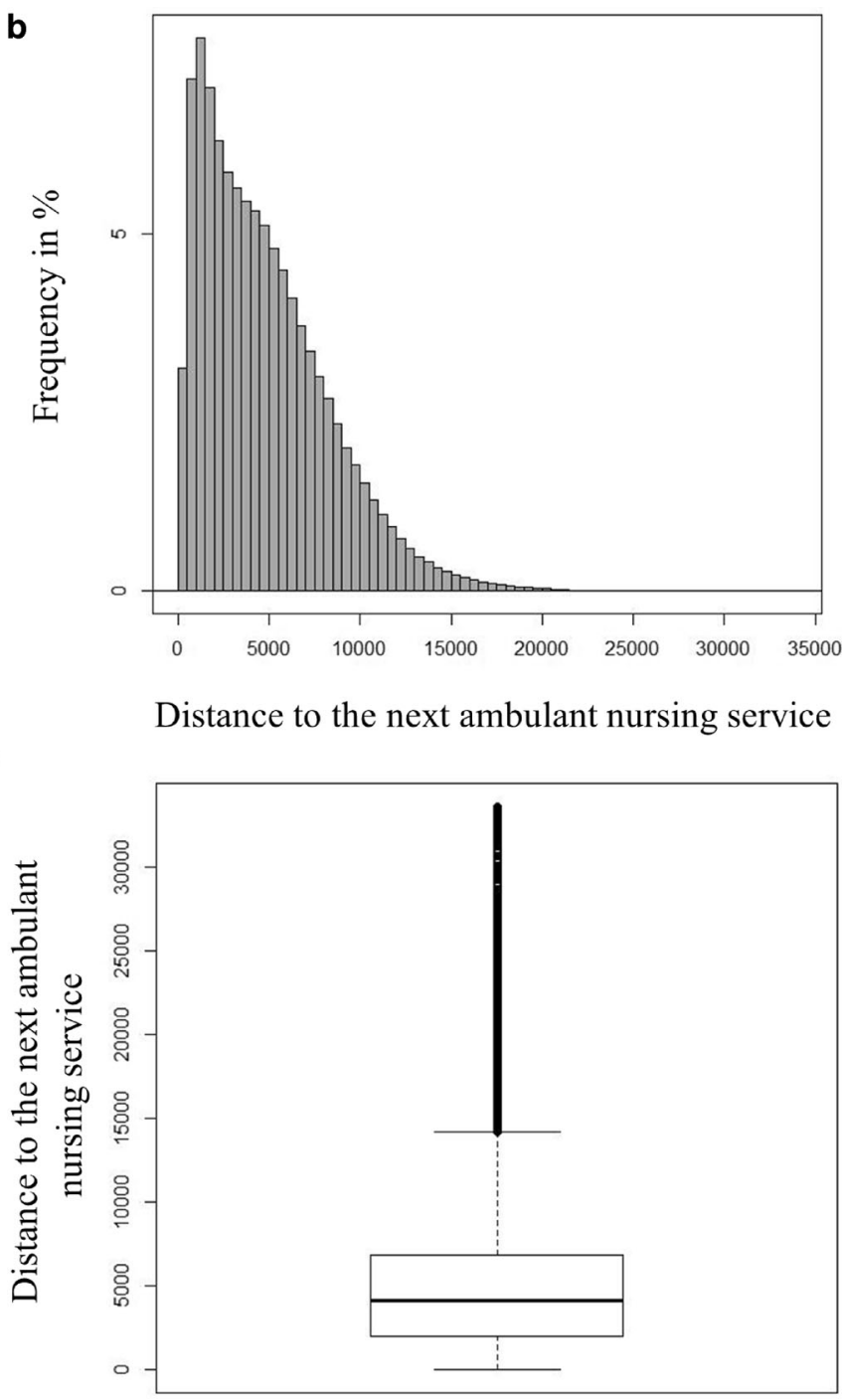

Distance to the next ambulant nursing service 
pared to the OSRM, the accessibility analysis upon which the study is based appears to perform quite well because the difference in the calculated distance-values between the two models is quite small.

\subsection{Common Radius of Action of Ambulant Nursing Services}

In contrast to other basic services, nursing services are not visited by their customers but deliver their services to the customers. A nationwide analysis of the service provision of ambulant nursing services based on a GIS accessibility analysis focuses on the question of whether and to what extent a dense network of ambulant nursing services has been developed to guarantee the nationwide provision of ambulant nursing services. Long or very long distances in rural areas could thus be indicative of potential undersupply. The following considerations are meant to begin to determine a threshold to be used throughout the analysis to identify long distances. This task is not easy because different thresholds can be found with regard to ambulant nursing services. The travel expenses cited in the service complexes can be related to driving costs, resulting in an average operating distance of $5 \mathrm{~km}$ at a speed of $50 \mathrm{~km} / \mathrm{h}$ (Neumeier 2015: 34). Nevertheless, because the long and short distances compensate for one another when service complexes are used, it can be assumed that this distance represents merely the average radius of action rather than the maximum. This finding is confirmed by Heiber (2002), a consultant specializing in nursing services, who claims that in Germany ambulant nursing services must cover an average of 4 to $5 \mathrm{~km}$ (at $50 \mathrm{~km} / \mathrm{h}$ ) to reach the customers. However, Heiber (2002) also claims that on average $23 \%$ of the overall working time of the nursing staff is spent on travel to the customers. He furthermore states that these averages hide variations in the values, which range from $14.5 \%$ to $43.9 \%$ of overall working time owing in part to the varying distances that need to be covered. A non-representative review of the radius of action explicitly recorded by a single ambulant nursing service revealed that the services analysed normally operate within a range up to $30 \mathrm{~km}$ (Neumeier 2015: 36). Taking these figures and Heiber's (2002) findings into account, it can be concluded that the maximum range of operation of ambulant nursing services lies somewhere from approximately 25 to $30 \mathrm{~km}$. This is then taken as the threshold for differentiating highly accessible regions from badly accessible regions in the remainder of this paper.

\section{Availability of Ambulant Nursing Services near the Place of Residence}

In Germany, according to the accessibility model, the average distance to the next ambulant nursing service that offers services according to SGB XI amounts to $4.8 \mathrm{~km}$. However, as mentioned earlier, such a country average hides important regional differences. Table 3 shows the average distances that an ambulant nursing service must cover to reach its customers, differentiated by the federal states and district types defined by the Federal Institute of Research on Building, Urban Affairs and Regional Development (BBSR) 2009 ${ }^{11}$. One can observe that the average distances to be covered differ between the different federal states. It is not surprising that the distances are the lowest in the city states (Hamburg, Berlin, Bremen). On average, the longest distances must be covered by nursing services that operate in Mecklenburg-Western Pomerania. In addition, the average distances to be covered increase from the urban areas to the sparsely populated rural areas in all of the federal states.

Based on an average driving speed of $50 \mathrm{~km} / \mathrm{h}$, an ambulant nursing service requires, on average, no more than a maximum of 10 minutes to reach its customers in any federal state or BBSR district type (2009) except for in district type 4, in Saxony Anhalt. However, although these figures give an initial indication about the provision of ambulant nursing services in Germany, small-scale intraregional differences are still hidden due to the regional aggregation level. Thus, it is quite interesting to analyse the accessibility situation at the smaller level of communities (LAU ${ }^{12}$ 2-Regions). Here, it can be observed that ambulant nurs-

\footnotetext{
11 These district types have been developed by the BBSR to assist in an interregional comparison of different region types within Germany at the level of administrative districts. They are defined as follows:

Type 1: Core cities in agglomerations (core cities, urban districts with more than 100,000 citizens);

Type 2: Densely populated districts in agglomerations (more than 300 citizens per $\mathrm{km}^{2}$ );.

Type 3: Highly populated districts in agglomerations (more than 150 citizens per $\mathrm{km}^{2}$ );

Type 4: Rural districts in agglomerations (districts with less than 150 citizens per $\mathrm{km}^{2}$ );

Type 5: Core cities in urbanized areas (cities with more than 100,000 citizens);.

Type 6: Densely populated areas in urbanized areas (districts with more than 150 citizens per $\mathrm{km}^{2}$ );

Type 7: Rural districts in urbanized areas (districts with less than 150 citizens per $\mathrm{km}^{2}$ );

Type 8: Densely populated rural areas (districts with more than 100 citizens per $\mathrm{km}^{2}$ );

Type 9: Sparsely populated rural areas (districts with less than 100 citizens per $\mathrm{km}^{2}$ ).

${ }^{12} \mathrm{LAU}=$ Local Administrative Unit, a basic component of the Nomenclature of Territorial Units for Statistics (NUTS), which is used in the European Union.
} 
Fig. $2 x / \widehat{y}$ data plot: Comparison of origin-destination distances calculated by the accessibility model with those calculated by the Open Source Routing Machine; Line Linear ordinary least square regression of the sample $(\hat{y}=$ $0.258+1.0417 x)$; Dots Distances to potential customers of ambulant nursing services calculated by the Open Source Routing Machine as a function of distances to potential customers of ambulant nursing services calculated by the accessibility model

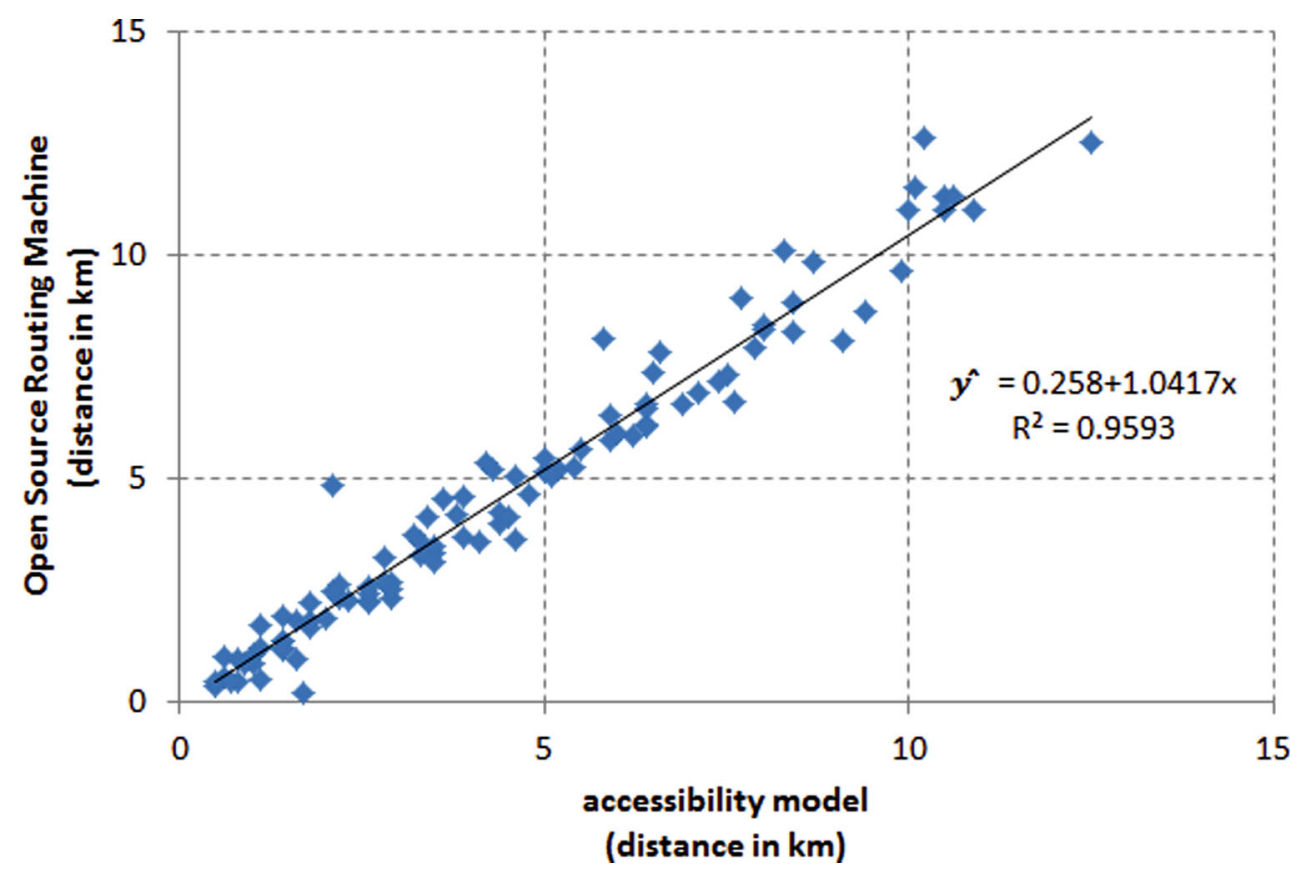

Table 3 Average distance to be covered by an ambulant nursing service to reach its customers according to the accessibility model, differentiated between federal states and BBSR district types 2009

\begin{tabular}{|c|c|c|c|c|c|c|c|c|c|c|}
\hline \multirow[t]{3}{*}{ Federal state } & \multirow[t]{2}{*}{$\varnothing$} & \multicolumn{9}{|c|}{ BBSR district type 2009} \\
\hline & & 1 & 2 & 3 & 4 & 5 & 6 & 7 & 8 & 9 \\
\hline & \multicolumn{10}{|c|}{ Average distance to be covered by an ambulant nursing service to reach its customers, in $\mathrm{m}$} \\
\hline Schleswig-Holstein & 5,567 & 1,889 & 3,039 & 4,813 & 4,661 & 1,986 & 5,813 & 6,345 & 6,068 & 6,324 \\
\hline Hamburg & 2,184 & 2,181 & 1,398 & 3,275 & & & & & & \\
\hline Lower Saxony & 5,824 & 807 & 3,694 & 5,332 & 6,311 & 2,794 & 5,200 & 6,455 & 6,472 & 8,598 \\
\hline Bremen & 2,493 & 2,438 & & & 3,658 & 2,730 & & & & \\
\hline North Rhine-Westphalia & 3,536 & 1,802 & 3,158 & 4,216 & 8,345 & 3,102 & 4,505 & 5,038 & & \\
\hline Hesse & 3,733 & 1,411 & 2,779 & 3,976 & & 1,181 & 3,380 & 5,226 & 4,768 & \\
\hline Rhineland-Palatinate & 5,336 & 1,559 & 2,355 & 4,205 & & 2,181 & 4,917 & 6,841 & & \\
\hline Baden-Württemberg & 4,515 & 1,536 & 3,168 & & 5,708 & 2,146 & 4,688 & 6,025 & 5,684 & \\
\hline Bavaria & 5,163 & 1,361 & 2,865 & 3,927 & 6,242 & 1,913 & 4,528 & 5,804 & 5,390 & 5,876 \\
\hline Saarland & 3,532 & 2,525 & 3,403 & 4,425 & & & 6,703 & & & \\
\hline Berlin & 1,384 & 1,383 & & & 3,841 & & & & & \\
\hline Brandenburg & 5,820 & 3,472 & & 7,533 & 5,781 & 2,679 & & 5,003 & 7,207 & 7,029 \\
\hline $\begin{array}{l}\text { Mecklenburg-Western } \\
\text { Pomerania }\end{array}$ & 6,255 & & & & & 2,991 & & 6,316 & 5,812 & 6,393 \\
\hline Saxony & 3,782 & 1,780 & & 4,105 & 4,744 & 1,954 & 3,508 & 4,638 & 4,402 & 7,954 \\
\hline Saxony-Anhalt & 5,667 & & & & 9,543 & 1,914 & 3,802 & 5,124 & 4,108 & 8,616 \\
\hline Thuringia & 4,831 & & & & & 2,998 & 4,745 & 4,891 & 4,916 & 5,845 \\
\hline Germany & 4,836 & 1,786 & 3,145 & 4,382 & 5,837 & 2,401 & 4,599 & 5,848 & 5,429 & 6,660 \\
\hline
\end{tabular}

Source: Neumeier (2015)

Rural district types are emphasized in italic

1 core cities in agglomerations; 2 densely populated districts in agglomerations; 3 highly populated districts in agglomerations; 4 rural districts in agglomerations; 5 core cities in urbanized areas; 6 densely populated areas in urbanized areas; 7 rural districts in urbanized areas; 8 densely populated rural areas; 9 sparsely populated rural areas 


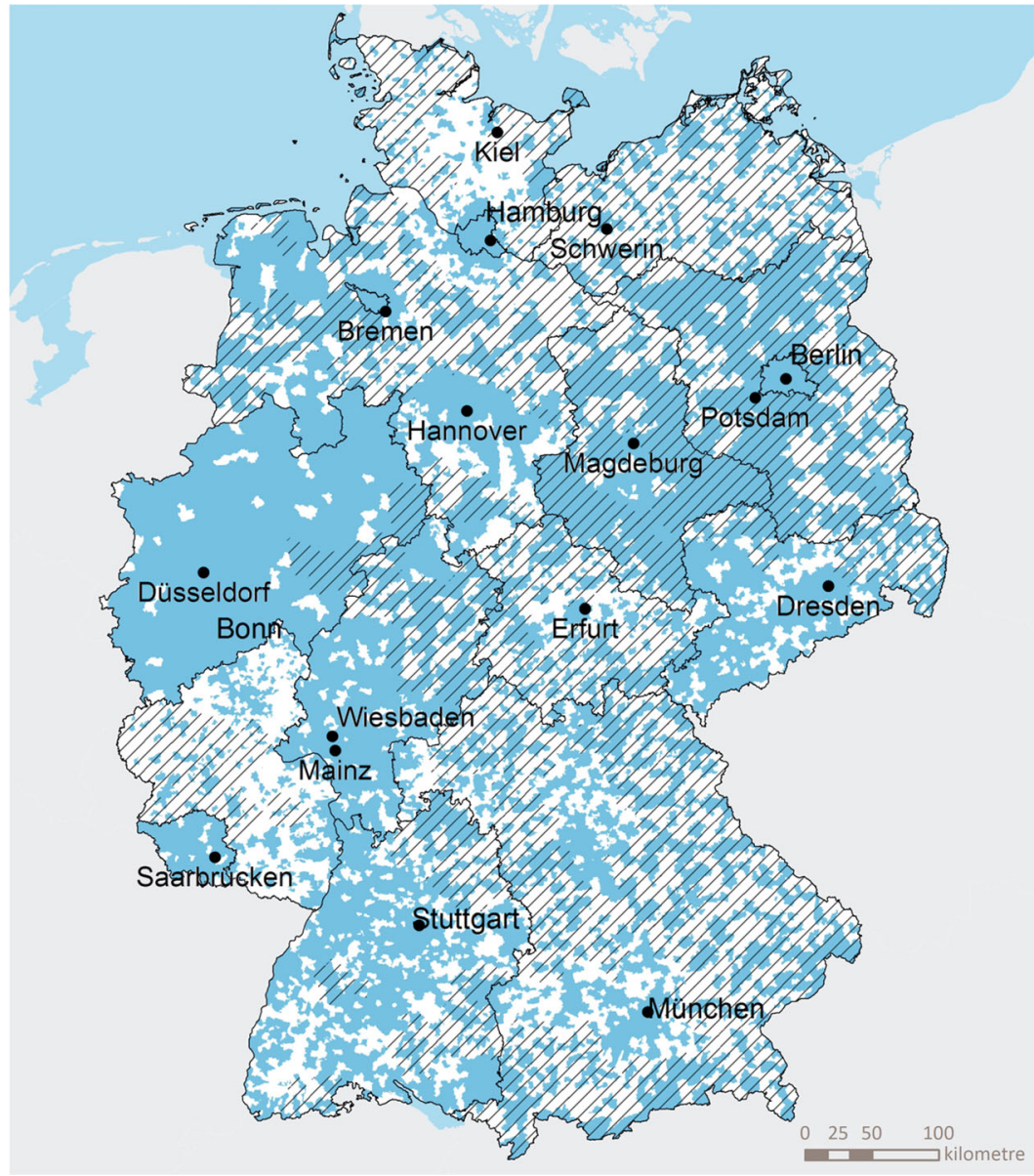

\section{Communities}

without location of an ambulant nursing service according to SGB XII

with at least one location of an ambulant nursing service according to SGB XI

\section{I//, Rural areas according to BBSR district} types 2009

Federal States

Fig. 3 Communities with and without at least one ambulant nursing service that offers services according to SGB XI. Administrative Boundaries: Bundesamt für Kartographie und Geodäsie (2010). (Data: Own calculations)

ing services are located in only $32 \%$ of the communities, whereas in $68 \%$ of the communities no ambulant nursing service exists (see Fig. 3).

What is striking is the high share of rural areas, according to the BBSR district types 2009 (shaded regions in Fig. 3), that do not have an ambulant nursing service ( $75 \%$ of the rural communities), especially in the federal states Rhineland-Palatinate, Schleswig-Holstein, Mecklenburg-Western Pomerania, Thuringia and in parts of Lower Saxony and Bavaria. However, does this absence of an ambulant nursing service in a community automatically mean that the availability of such services is problematic in the communities concerned? To answer this question, we must look more closely at the distances and driving times for ambulant nursing services with respect to community averages (see Figs. 4 and 5). In $58 \%$ of the communities, the distance that an ambulant nursing service must cover to reach its potential customers is on average less than or equal to $6 \mathrm{~km}$, which corresponds to a driving time of approximately 7 minutes at a speed of $50 \mathrm{~km} / \mathrm{h}$.

For a further $30 \%$ the average distance is less than or equal to $10 \mathrm{~km}$, which corresponds to a driving time of ap- proximately 12 minutes at a speed of $50 \mathrm{~km} / \mathrm{h}$. In another $10 \%$ of the communities, the average distance to be covered is less than or equal to $15 \mathrm{~km}$, which corresponds to a driving time of 18 minutes at a speed of $50 \mathrm{~km} / \mathrm{h}$. Thus, only in approximately $1 \%$ of the communities does an ambulant nursing service have to cover distances that are longer than $15 \mathrm{~km}$, or drive more than 18 minutes, to reach its potential customers (dark red coloured communities in Figs. 4 and 5). Classifying communities according to the driving distances (Fig. 5) reveals especially clearly that there are only a very few communities where, on average, an ambulant nursing service must spend more than 30 minutes (which can be defined as the threshold for bad accessibility) reaching its potential customers, mainly in the far eastern part of Lower Saxony. The urban-rural accessibility divide identified by considering accessibility according to the BBSR district types 2009 can also be clearly observed when looking at community averages. According to the accessibility model, assuming an average speed of $50 \mathrm{~km} / \mathrm{h}$, average driving times of approximately 10 minutes prevail in rural communities (shaded regions in Figs. 4 and 5), whereas in urban communities average driving times of approximately $5 \mathrm{~min}$ - 


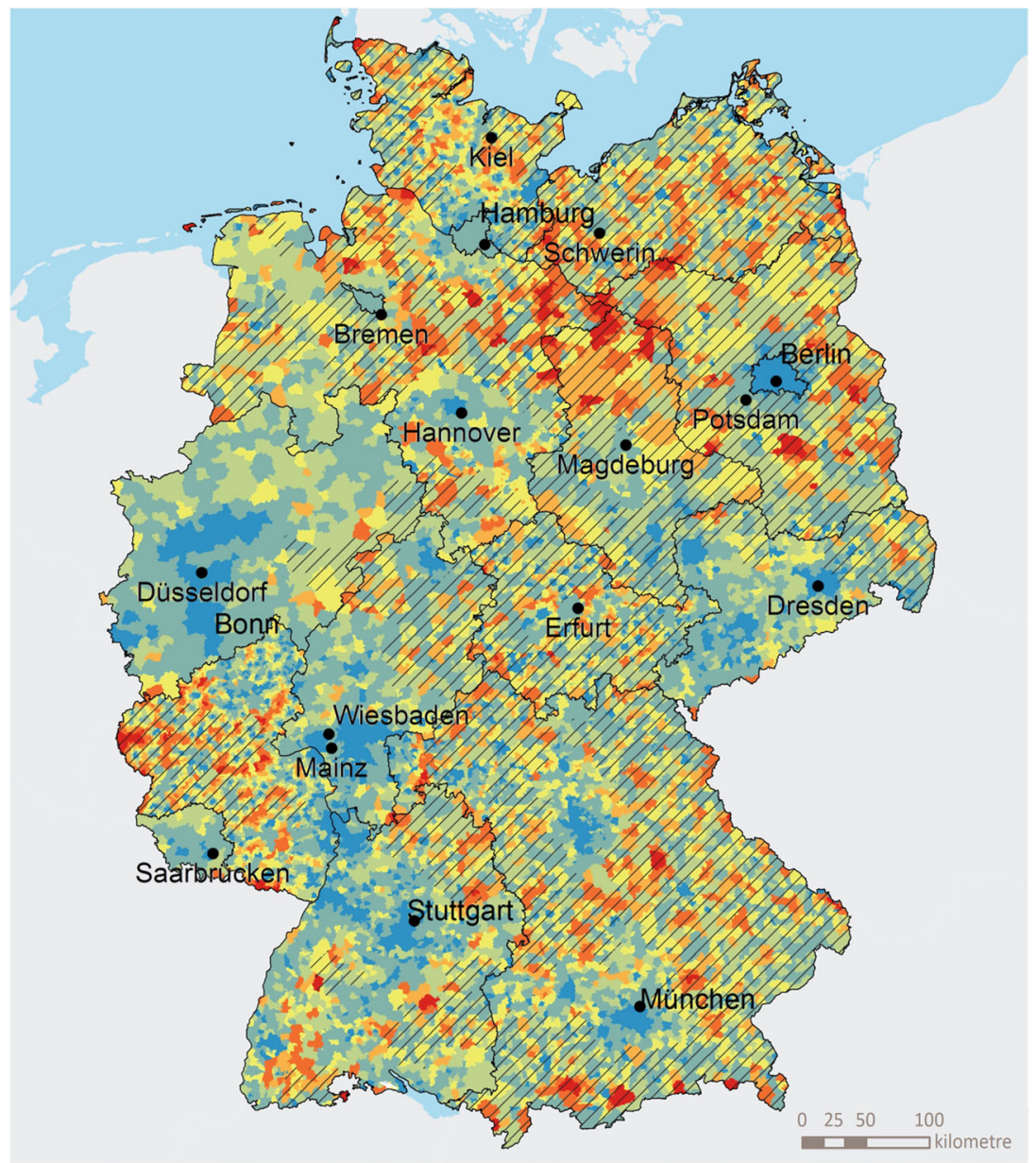

\section{Average distance that an ambulant nursing service must cover to reach its customers, according to SGB XI}

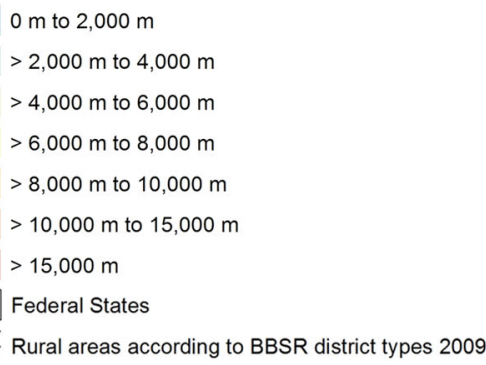

Rural areas according to BBSR district types 2009

Fig. 4 Average distance to be covered by an ambulant nursing service that offers services according to SGB XI to reach its potential customers at the community level. Administrative Boundaries: Bundesamt für Kartographie und Geodäsie (2010). (Data: Own calculations)

utes prevail (see Fig. 5). However, as with federal state or district type averages, community averages only allow the average accessibility situation within a certain administrative level to be assessed. Interesting intraregional differences may be hidden. Thus, to comprehensively assess the availability of ambulant nursing services near the place of residence on a small scale - below the level of administrative units - a closer look at the results of the accessibility analysis on the level of the single raster cells of the analysis raster is necessary. In Figs. 6 and 7, similar to the analysis at the community level, the distances to be covered and the driving times needed to reach the potential customers at the level of the single raster cells of the analysis raster are depicted in the form of two heat maps. According to the accessibility model, there are only $375(0.02 \%)$ raster cells out of the 1,667,191 raster cells of the countrywide analysis raster (raster cells in Hamburg as well as the counties (NUTS $\left.{ }^{13}-3\right)$ Leer, Gifhorn, Lüchow-Dannenberg in Lower

\footnotetext{
13 The Nomenclature of Territorial Units for Statistics is an administrative division used in the European Union for statistical purposes.
}

Saxony; Rhein-Kreis Neuss in North-Rhine Westphalia; Eifelkreis Bitburg-Prüm in Rhineland-Palatinate; Göppingen, Breisgau-Hochschwarzwald in Baden-Württemberg; Oberallgäu, Bad Tölz-Wolfratshausen in Bavaria, Prignitz in Brandenburg; Stendal, Altmarkkreis Salzwedel in Saxony-Anhalt) where the next ambulant nursing service must cover more than $25 \mathrm{~km}$ to reach its potential customers.

According to the accessibility model, only $0.008 \%$ of the German population lives in these regions. In 107 raster cells $(0.006 \%)$ (raster cells in the counties Prignitz in Brandenburg; Lüchow-Dannenberg, and the island Borkum in the district Leer in Lower Saxony), according to the accessibility model, an ambulant nursing service must cover a distance that is greater than $30 \mathrm{~km}$ to reach its potential customers. A total of $0.006 \%$ of the German population lives in these regions (Neumeier 2015: 50-51). Thus, as can be clearly seen, ambulant nursing services only have to cover distances greater than $25 \mathrm{~km}$ to reach their potential customers in very few, sparsely populated regions of Germany. Considering the threshold of $30 \mathrm{~km}$, the share of regions that is affected is almost negligible. The already 


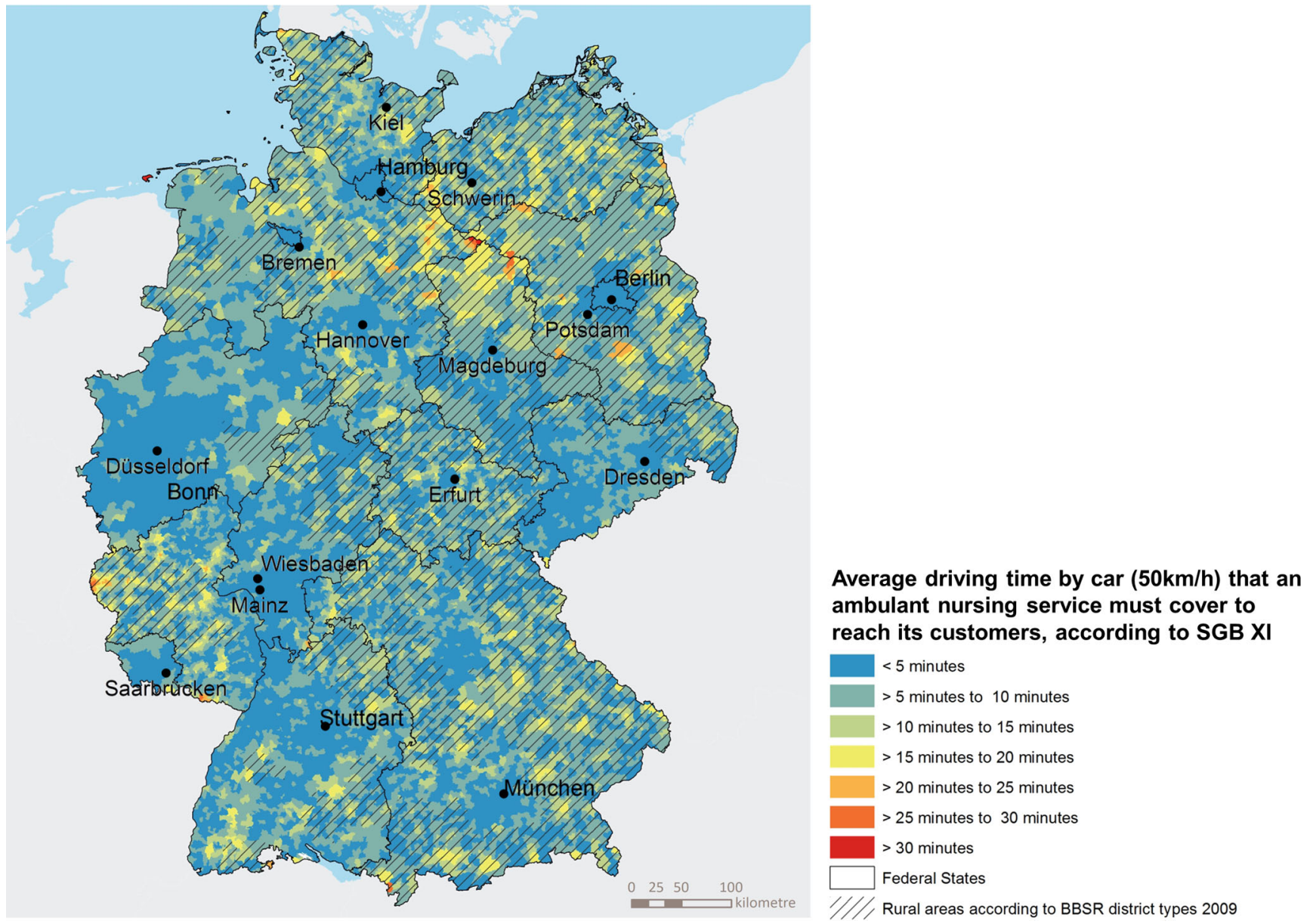

Fig. 5 Average travel time in minutes of an ambulant nursing service that offers services according to SGB XI to reach its potential customers on a community level by car (speed $50 \mathrm{~km} / \mathrm{h}$ ). Administrative Boundaries: Bundesamt für Kartographie und Geodäsie (2010). (Data: Own calculations)

identified urban-rural divide can also be clearly detected at the level of single raster cells (see Figs. 6 and 7 as well as Table 4). Looking at Figs. 6 and 7, it is quite obvious that ambulant nursing services must cover greater distances and allow more driving time in rural areas than in urban areas. A summary, showing the number of cells of the analysis raster where a certain distance must be covered (expressed as driving time), as differentiated according to the BBSR district types 2009, is given in Table 5. These results suggest that there might be a correlation between population density and the distances to be covered to the next ambulant nursing service. To analyse the existence as well as the strength of this relation we decided to perform a regression analysis. The scatter plot (Fig. 8a) clearly shows a curvilinear relation between population density and distance to the next ambulant nursing service. This was due to the highly skewed value distributions of the distances to the next ambulant nursing service (Fig. $8 \mathrm{~b}^{14}$ ) and specifically of the population density (population per $\mathrm{km}^{2}$ ) (Fig. 8e).

14 The graphical representation of the fit-plot is based on a random sample of the overall data set because of constraints of the statistical
Both were therefore subjected to a log-transformation prior to the analysis (Fig. 8d and c).

Furthermore, we decided to exclude observations with a population density of 0 (Fig. 8f $)^{15}$. These corrected values were subjected to an ordinary least square log-log regression, using following model:

$\log \left(d_{\text {pflege }}\right)=\beta_{0}+\beta_{1} \log \left(\right.$ pop $\left.p_{\text {dens }}\right)+\epsilon$

software concerning the number of values to be used for graphical representations. The full data set shows a mean of 9.6, variance of 181.2, skewness of 4.7 and kurtosis of 38.6. The sample used for the representation shows a mean of 9.8 , variance of 180.6 , skewness of 4.9 and kurtosis of 41. As such it is reasonable to assume that the random sample represents a representative subset of the full data set. That is, the overall graphical depiction of the random sample does not differ significantly from a graphical depiction based on the full data set.

15 When specifying grid cells as inhabited not only cells with a population value $>0$ have been chosen, but also additional cells with a population $=0$ according to the EWZ 250 that contain building coordinates according to the data set "Hauskoordinaten Deutschland" of the survey offices of the federal states. 


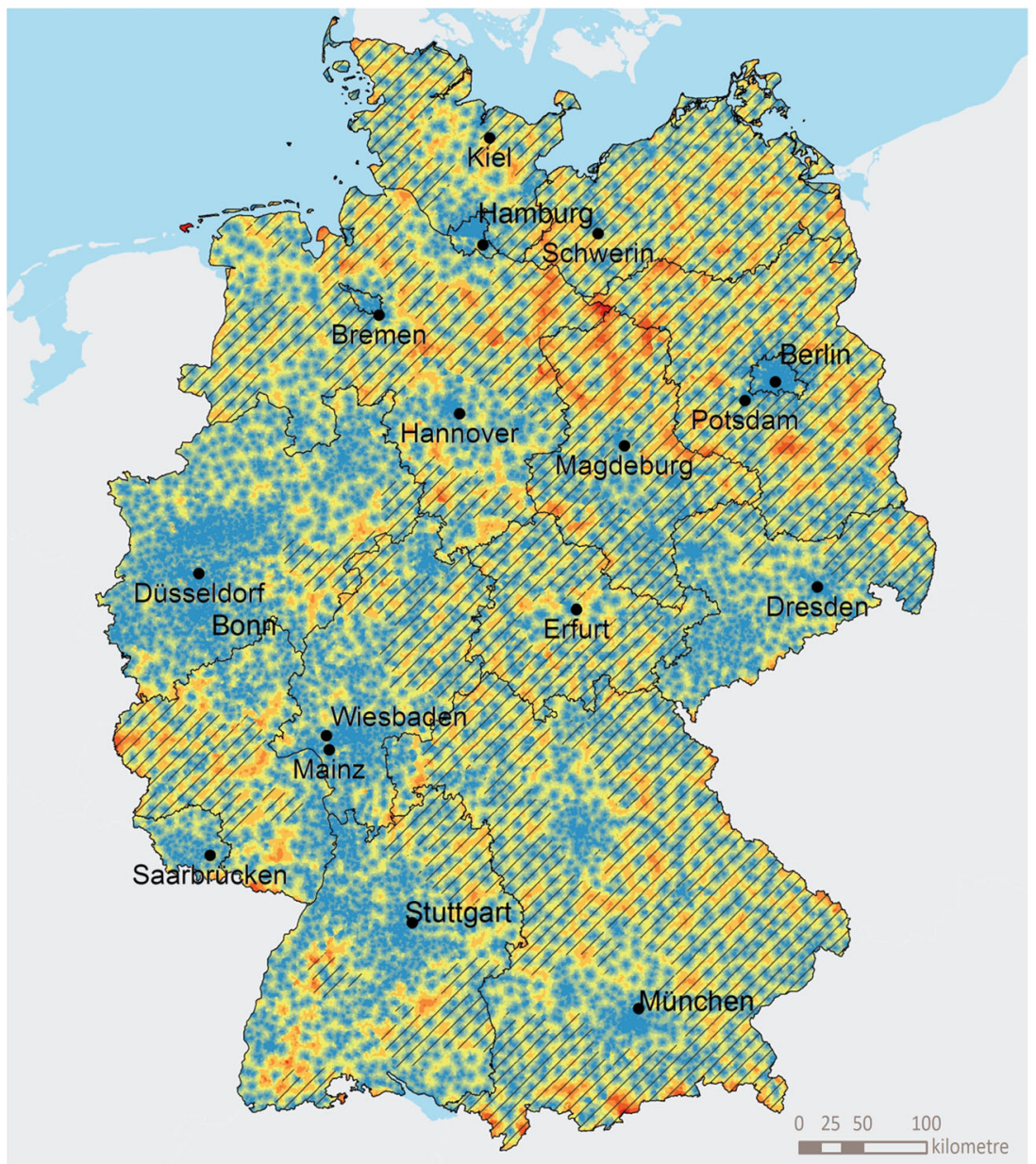

\section{Distance that an ambulant nursing service must cover to reach its customers, according to SGB XI}

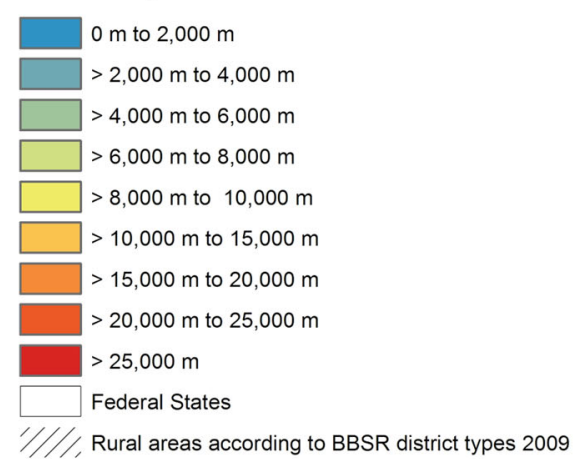

Fig. 6 Distance to be covered by an ambulant nursing service that offers services according to SGB XI to reach its potential customers at the level of the EWZ 250 raster cells. Administrative Boundaries: Bundesamt für Kartographie und Geodäsie (2010). (Data: Own calculations)
$d_{\text {pflege }}$
distance to the next ambulant nursing service
pop $_{\text {dens }}$ population density

The results of the regression are summarized in Table 6 as well as in Fig. 8b. All in all, the regression analysis delivered a $R^{2}$ of 0.16 , indicating that $16 \%$ of the variation in the distances to the next ambulant nursing service can be explained by the population density. Due to the double logtransformation the estimated coefficient can be interpreted as elasticity. That is, the distance to the next ambulant nursing service decreases by around $0.2 \%$ if the population density increases by around $1 \%$. This observation suggests that in regions with a low population density (rural regions) the population density has a greater absolute influence on the distance to the next ambulant nursing service than in regions with a high population density (urban regions) (see also Fig. 8a). However, it can also be seen that population density can only partially explain overall variation in the data set of distances to the next ambulant nursing service. This is an indication that other factors, which still need to be defined, also affect the distances to be covered to reach an ambulant nursing service.

In addition to considering distances and driving times to assess the availability of an ambulant nursing service that offers services according to SGB XI near the place of residence, it is also interesting to take a closer look at how many potential customers can be reached within a specific distance with regard to the driving time. To obtain an indication, we added the inhabitants of the raster cells of the EWZ 250 that can be reached within a certain driving time (see Table 5). Gaining an impression of the situation for people who are in need of care as well as for those who actually make use of an ambulant nursing service is also of interest. For every raster cell, the (statistical) share of people who are in need of care was therefore calculated based on the share of people who are in need of care in the county that the raster cells fall into, according to the nursing statistics of 2013 (which contains data for 2011) (see Statistisches Bundesamt 2013d). Based on this value, the share of people who actually use an ambulant nursing service ( $23 \%$ of people in need of care, Statistisches Bun- 


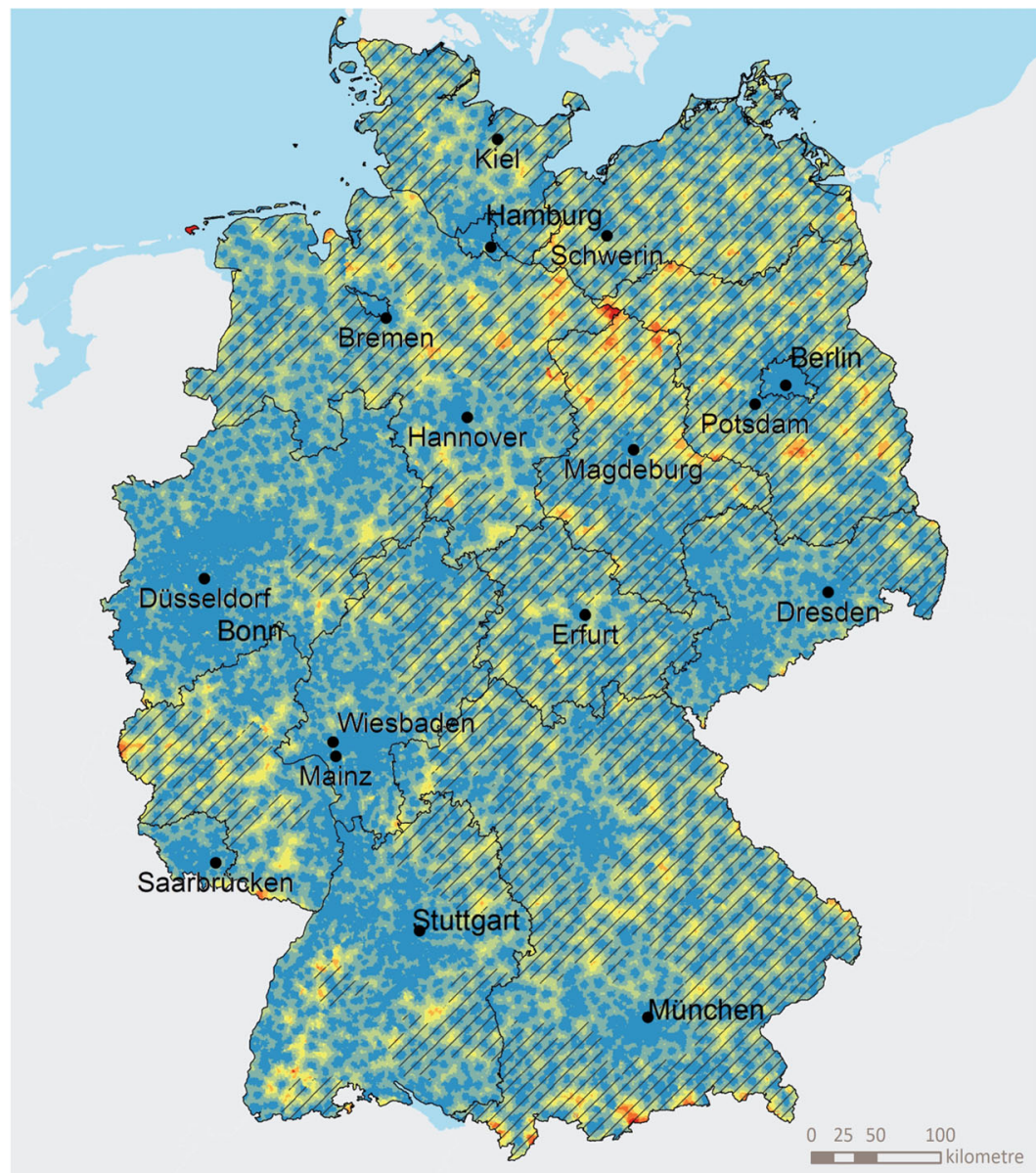

\author{
Driving time by car $(50 \mathrm{~km} / \mathrm{h})$ that an ambulant \\ nursing service must cover to reach its \\ customers, according to SGB XI

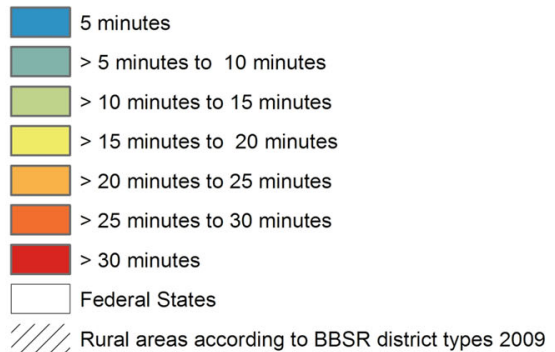

Fig. 7 Travel time in minutes by car for an ambulant nursing service that offers services according to SGB XI to reach its potential customers at the level of the EWZ 250 raster cells (speed $50 \mathrm{~km} / \mathrm{h}$ ) Administrative Boundaries: Bundesamt für Kartographie und Geodäsie (2010). (Data: Own calculations)

desamt 2013c: 12) was determined for every raster cell. However, it must be acknowledged that these statistically calculated values are not an accurate representation of reality because they are based on an equal distribution over the raster cells under consideration, and disregard, for example, the real place of residence of the people who are in need of care. There is no data available that would allow for the estimation of the availability and accessibility of the ambulant nursing services that offer services accord- ing to SGB XI in this way. The accessibility model shows that in Germany, $94 \%$ of people and $95 \%$ of those who use an ambulant nursing service can be reached by an ambulant nursing service within a maximum driving time of 10 minutes (at $50 \mathrm{~km} / \mathrm{h}$ ). The share of people who use an ambulant nursing service and who cannot be reached by an ambulant nursing service within 20 minutes is negligible $(0.19 \%)$ from a nationwide perspective. 


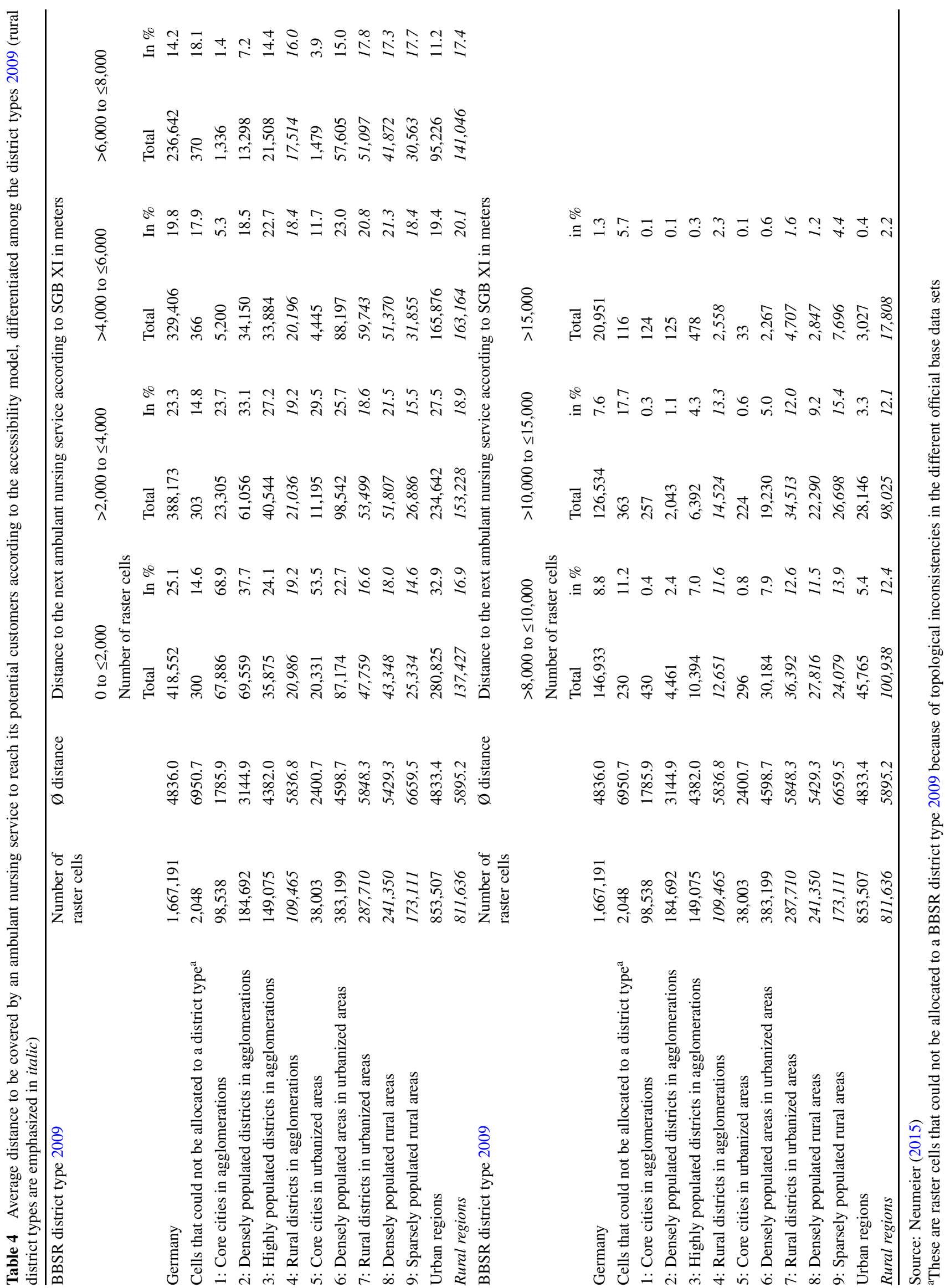




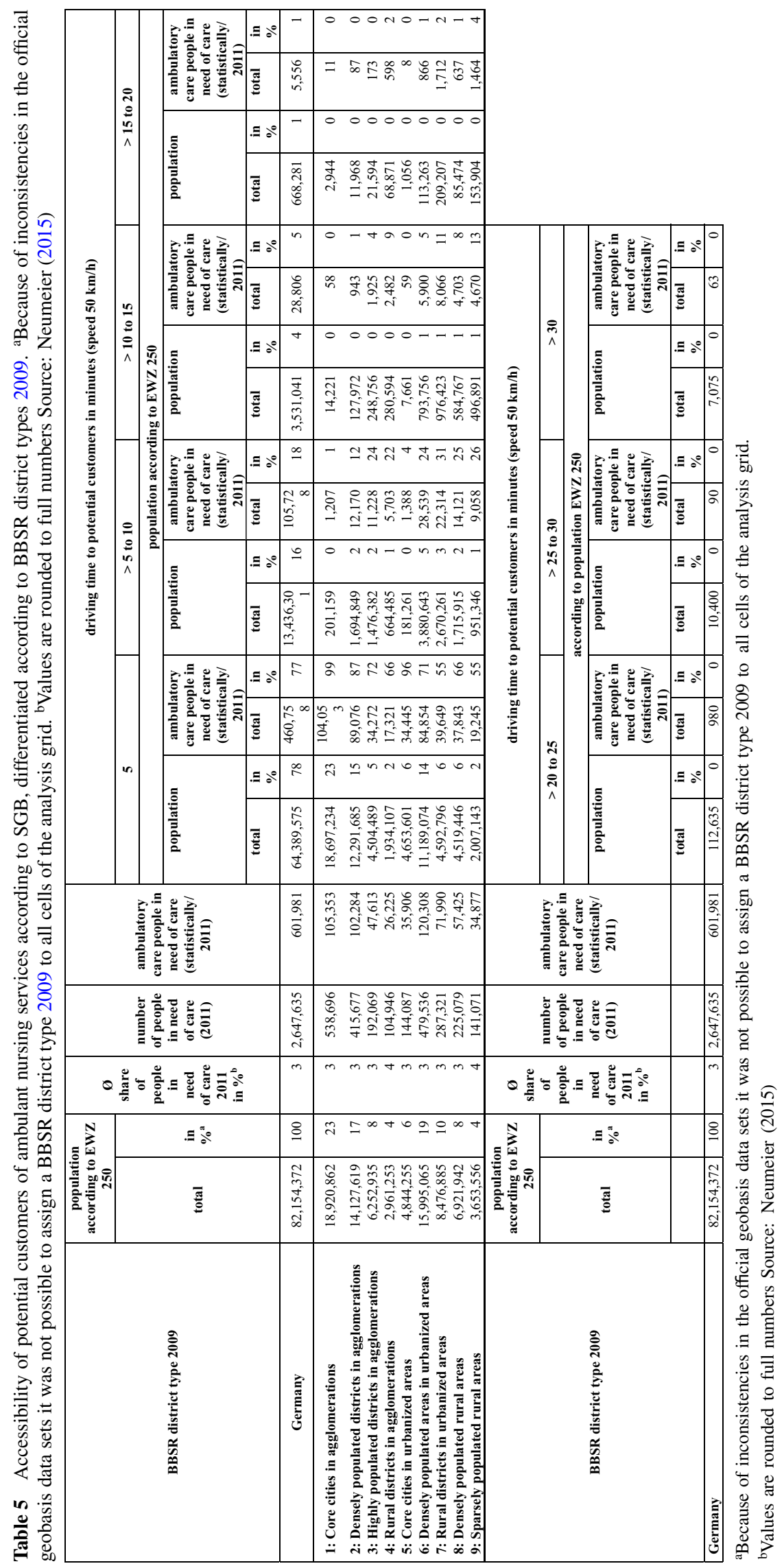


a
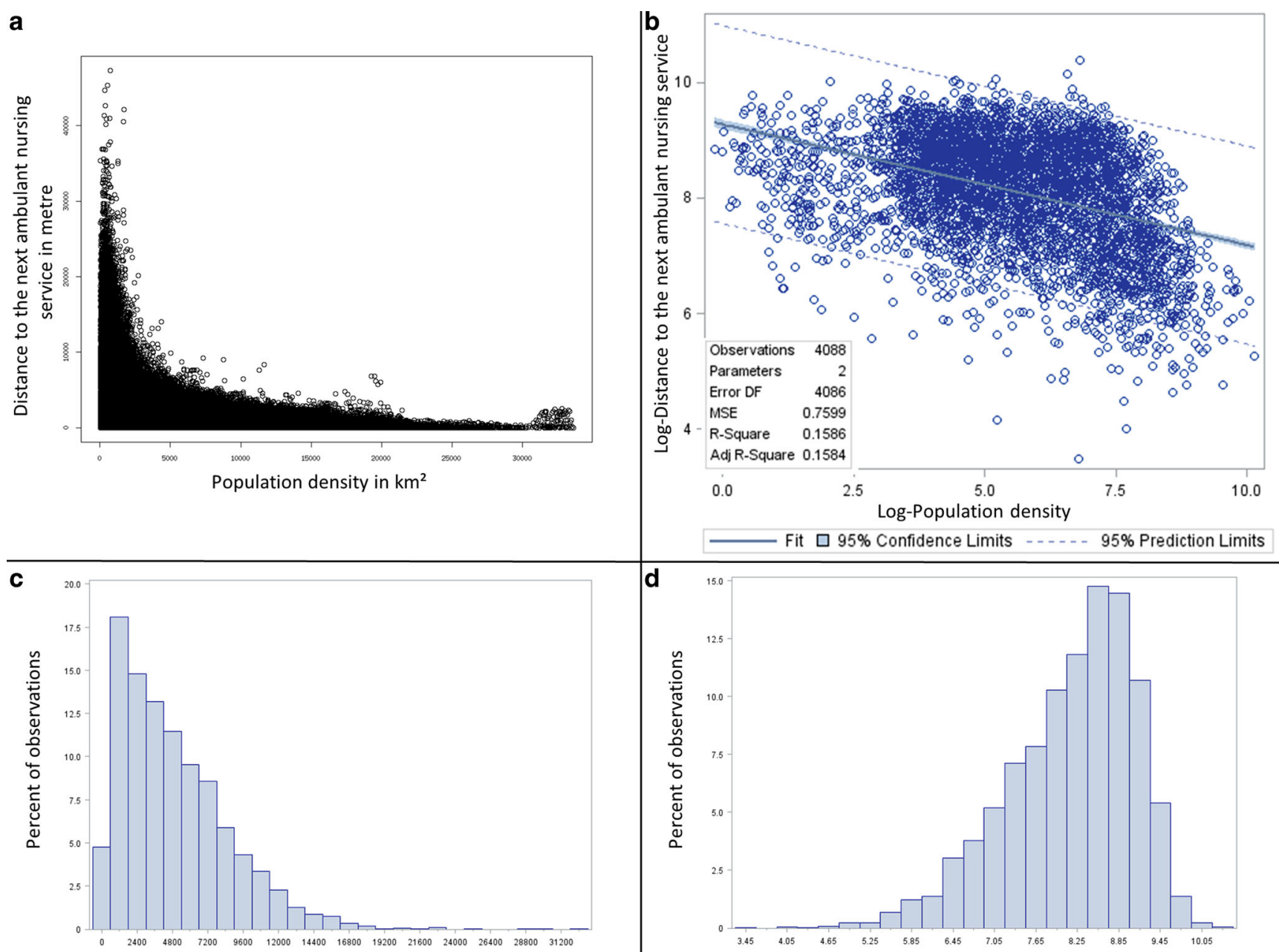

Distance to the next ambulant nursing service in metre

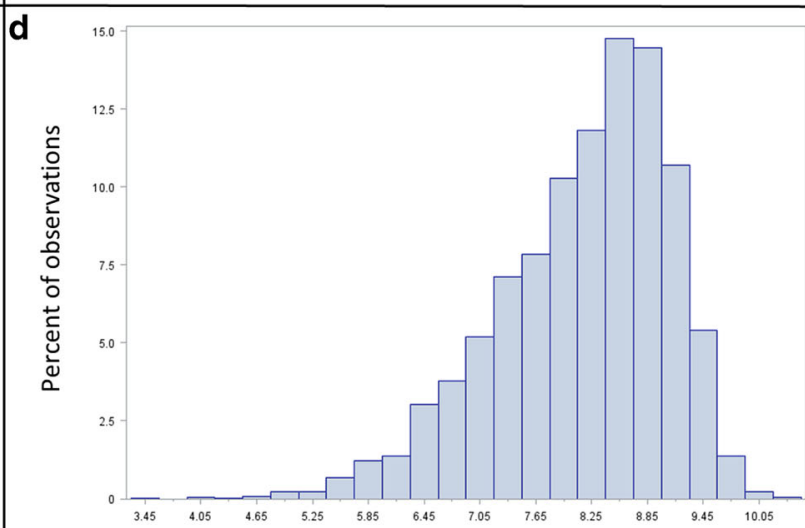

Log-Distance to the next ambulant nursing service
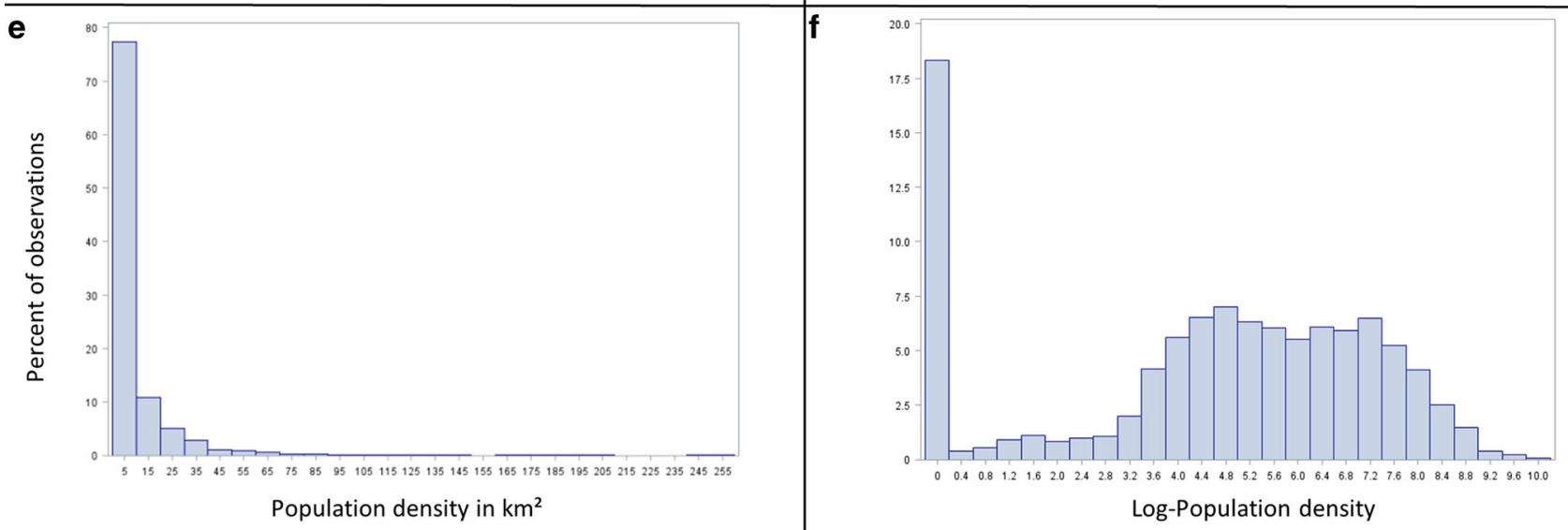

Fig. 8 Data distribution and fit-plot of distance to the next ambulant nursing service as a function of population density. (Data: Own calculations) 
Table 6 Summary of regression analysis between population density and distance to the next ambulant nursing service (observations with a population density of 0 were excluded $\left.{ }^{15} ; N=1,366,979\right)$

\begin{tabular}{|c|c|c|c|c|c|}
\hline \multicolumn{6}{|l|}{ Analysis of Variance } \\
\hline Source & DF & Sum of squares & Mean square & $F$ Value & $\operatorname{Pr}>F$ \\
\hline Model & 1 & 190,164 & 190,164 & 261,194 & $<0.0001$ \\
\hline Error & $1,370,000$ & 995,237 & 0.72806 & & \\
\hline Corrected Total & $1,370,000$ & $1,185,401$ & & & \\
\hline \multicolumn{6}{|l|}{ Parameter Estimates } \\
\hline Variable & DF & Parameter estimates & Standard error & t Value & $\operatorname{Pr}>|t|$ \\
\hline Intercept & 1 & 9.25649 & 0.00237 & 3906,22 & $<0.0001$ \\
\hline Log population density & 1 & -0.20573 & 0.00040254 & $-511,07$ & $<0.0001$ \\
\hline \multicolumn{6}{|c|}{ Dependent Variable: logarithmized distance to the next ambulant nursing service } \\
\hline Dependent Mean: 8.10428 & \multicolumn{2}{|c|}{ Root MSE: 0.85326} & \multicolumn{3}{|c|}{ Adj. $R$-Square: 0.1604} \\
\hline$R$-Square: 0.1604 & \multicolumn{5}{|c|}{ Adj. $R$-Square: 0.1604} \\
\hline
\end{tabular}

\section{Summary and Conclusions}

The main findings of the analysis of the regional distribution of ambulant nursing services near the place of residence in Germany, based on the modelling of customer accessibility, can be summarized as follows:

- Since 2003, a steady increase in the number of providers of ambulant nursing services according to SGB XI can be observed. Today, with 13,466 providers according to the nursing-service-navigator of the AOK (German public health insurance company), there are 2,646 more providers than in $2001(10,820)$ (Neumeier 2015: 67).

- In Germany, 3.1\% of the population is in need of care. Of these, $23 \%$ make use of ambulant nursing services that offer services according to SGB XI (Statistisches Bundesamt 2013c: 8, 12). In the coming years, the share of people in need of care is likely to increase because of overall demographic developments. It is assumed that especially in the federal states MecklenburgWestern Pomerania, Brandenburg, Saxony, Saxony-Anhalt and Thuringia, the proportion of elderly people will increase until 2030, and thus it can be expected that especially in these regions the share of those in need of care will also increase.

- It can be established that the maximum radius of action of an ambulant nursing service that offers services according to SGB XI is between 25 and $30 \mathrm{~km}$. In addition, according to a study by Büscher/Horn (2010), ambulant nursing services very seldom reject a request for home care service due to bad accessibility of the customers or because the customers do not live within the usual radius of action.

- According to the accessibility model, an ambulant nursing service must on average drive $(50 \mathrm{~km} / \mathrm{h}) 5$ minutes in urban and 7 minutes in rural areas to reach its potential customers. Nevertheless, these average driving times hide intraregional differences. Considering accessibility on a small scale based on $250 \mathrm{~m}$ raster cells, it can be seen that, especially in rural areas, driving times are up to 20 minutes and, in some isolated cases, even 25- to 30-minute drives are necessary.

- Approximately $82 \%$ of the population and $80 \%$ of people who are in need of care can be reached by an ambulant nursing service within 6 minutes $(50 \mathrm{~km} / \mathrm{h})$. Within 10 minutes, $94 \%$ of people and $95 \%$ of those in need of care can be reached. In contrast, the share of people who cannot be reached within a distance of 30 kilometres $(0.006 \%)$ is negligible from a nationwide point of view.

- The accessibility model does not account for mobility chains, whereby a combination of different customer addresses are visited within a single tour by an ambulant nursing service, because such data are not available. Thus, it can be assumed that the accessibility model overstates the distances to be covered, which relativizes the modelled situation in the few regions that display disadvantageous accessibility values $(>25 \mathrm{~km})$.

Taking all these aspects into consideration, it is possible to conclude that at present, in Germany, the basic availability of an ambulant nursing service near the place of residence is guaranteed in urban as well as rural areas throughout the country. Nevertheless, because the nursing market offers few opportunities for advancement and the care is strenuous and badly paid, this market is relatively tight. It can therefore be expected that nursing personnel will decrease, especially in the less attractive peripheral regions (Slupina/Sütterlin/Klingholz 2015: 35-40). This decrease poses the danger that in the future the provision of ambulant nursing services will degrade, especially in sparsely populated peripheral rural areas, if the current developments in the nursing market are not counteracted. A scenario that was calculated using the accessibility model (Neumeier 
2015) revealed that possible business closures of ambulant nursing services will have an especially negative effect on the availability of such services in north-eastern SaxonyAnhalt and north-eastern Lower Saxony as well as in the west and south of Rhineland-Palatinate.

Although it could be shown that the distances to the next ambulant nursing service depend to a considerable extent on population density, the analysis also revealed that other factors also influence the distances to be covered. These factors have still to be identified. Thus, further research is necessary to fully understand the factors concerned and their mode of functioning as to the distances to be covered to reach the next ambulant nursing service. Another aspect that the analysis could not determine is where shortages in the provision of care are likely because of the staffing of the individual ambulant nursing services; this was impossible due to a lack of data. A model that was based on potential customers within catchment areas and county averages for employees would in principle allow a rough estimation to be made, but it would not identify underemployed service locations because these are masked in the county data.

When considering who is affected or disadvantaged by poor accessibility of ambulant nursing services in rural areas, the questions arise as to how people cope with this situation, how they are affected, and what this arrangement means for their overall living conditions. These questions cannot be answered by a quantitative accessibility analysis. Nevertheless, against the background of the German discourse on Daseinsvorsorge as well as the European discourse on territorial cohesion, such quantitative findings are important. Although a consensus appears to exist that, especially in rural areas, living conditions are deteriorating and the availability of basic services is declining, there is little data that allows us to assess the dimension of the decrease in basic services and identify services and regions that are especially affected. Thus, quantitative accessibility analyses and studies such as the one presented in this paper provide important contributions toward gaining deeper knowledge about the availability of basic services throughout Germany. They furthermore help to create a data basis for the political and scientific discourse on Daseinsvorsorge and territorial cohesion, and they identify regions and services that are in need of in-depth research and political intervention, as well as those where no urgent action is needed.

Acknowledgements I would like to express my sincere appreciation to my colleague Dr. Magarian for her valuable advice concerning the analysis of the correlation between population density and distance to the next location of an ambulant nursing service.

\section{Appendix}

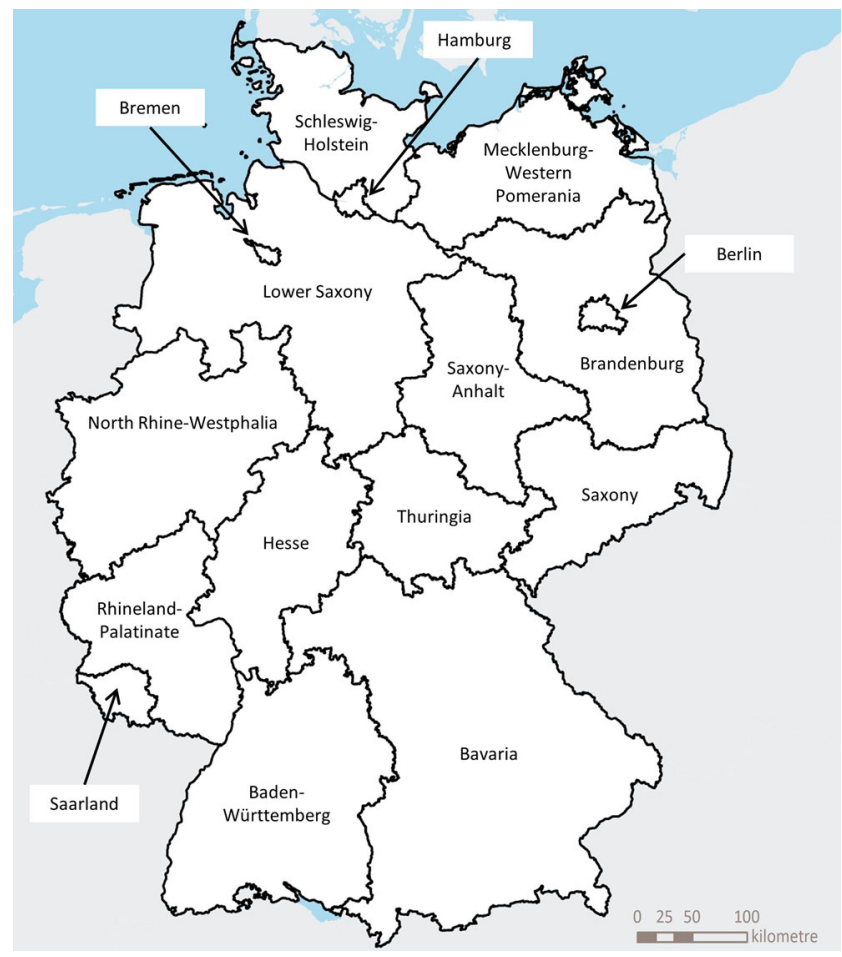

Fig. 9 Federal States of Germany. Administrative Boudaries: Bundesamt für Kartographie und Geodäsie (2013)

\section{References}

BBSR - Bundesinstitut für Bau-, Stadt- und Raumforschung (2009): Karte Siedlungsstrukturelle Kreistypen: Stand 2009. Bonn.http://www.bbsr.bund.de/BBSR/DE/Raumbeobachtung/ Raumabgrenzungen/SiedlungsstrukturelleGebietstypen/ Kreistypen/Downloadangebote.html (Zugriff am 25.04.2016).

BBSR - Bundesinstitut für Bau-, Stadt- und Raumforschung (2015): Hochbetagte und soziale Netze. Bonn. http://www.bbsr.bund. de/BBSR/DE/Raumbeobachtung/UeberRaumbeobachtung/ Komponenten/Raumordnungsprognose/Download_ROP2035/ K5_Hochbetagte_sozialeNetze_1235.jpg (Zugriff am 25.04.2016).

Bleisch, A. (2005): Die Erreichbarkeit von Regionen. Ein Benchmarking-Modell. Basel. Dissertation, Universität Basel.

Bleisch, A.; Koellreuter, C. (2003): Die Erreichbarkeit von Regionen. Basel.

BMVBS - Bundesministerium für Verkehr, Bau und Stadtentwicklung (Hrsg.) (2010): Sicherung der Daseinsvorsorge und ZentraleOrte-Konzepte - gesellschaftspolitische Ziele und räumliche Organisation in der Diskussion. Berlin. = BMVBS-OnlinePublikation, 12/2010. http://www.bbsr.bund.de/cln_016/nn_ 21918/BBSR/DE/Veroeffentlichungen/BMVBS/Online/2010/ ON122010.html (Zugriff am 26.04.2016).

BMVBS - Bundesministerium für Verkehr, Bau und Stadtentwicklung (Hrsg.) (2013): Nahversorgung in ländlichen Räumen. Berlin. = BMVBS-Online-Publikation, 02/2013. http://www. bbsr.bund.de/BBSR/DE/Veroeffentlichungen/BMVBS/Online/ 
2013/DL_ON022013.pdf?_blob=publicationFile\&v=2 (Zugriff am 26.04.2016).

Born, K.M. (2009): Anpassungsstrategien an schrumpfende Versorgungsstrukturen - Beispiele aus Brandenburg und Niedersachsen. In: Neu, C. (Hrsg.): Daseinsvorsorge. Eine gesellschaftswissenschaftliche Annäherung. Wiesbaden, 133-153.

Burgdorf, M. (2010): Disaggregation von Bevölkerungsdaten mittels ATKIS Basis DLM. In: Strobl, J.; Blaschke, T.; Griesebner, G. (Hrsg.): Angewandte Geoinformatik 2010: Beiträge zum 22. AGIT-Symposium Salzburg. Berlin, 474-483.

Burgdorf, M.; Krischausky, G.; Müller-Kleißler, R. (2015): Indikatoren zur Nahversorgung. Erreichbarkeit von Gütern und Dienstleistungen des erweiterten täglichen Bedarfs. Bonn. = BBSR-Analysen KOMPAKT, 10/2015.

Büscher, A.; Horn, A. (2010): Bestandsaufnahme zur Situation in der ambulanten Pflege. Ergebnisse einer Expertenbefragung. Bielefeld. $=$ Veröffentlichungsreihe des Instituts für Pflegewissenschaft an der Universität Bielefeld, P10-145.

Dahlgren, A. (2008): Geographic Accessibility Analysis - Methods and Application. Lund. Dissertation, Lund Institute of Technology. http://www.dissertations.se/dissertation/ff24596a13/ (Zugriff am 25.04.2016).

Deutsches Medizinrechenzentrum (2013): Gefahr für ambulante Pflegedienste? http://dmrz.de/pflege-neuausrichtungsgesetzgefahr-pflegedienste.pdf (Zugriff am 25.04.2016).

Einig, K. (2008): Regulierung der Daseinsvorsorge als Aufgabe der Raumordnung im Gewährleistungsstaat. In: Informationen zur Raumentwicklung 1/2, 17-40.

European Commission (2014): Territorial cohesion. http://ec.europa. eu/regional_policy/archive/consultation/terco/paper_terco_en. pdf (Zugriff am 03.05.2016).

Favry, E. (2006): Aufrechterhaltung der Funktionsfähigkeit ländlicher Räume. Dienstleistungen der Daseinsvorsorge und Regionale Governance. Wien. = ÖROK-Schriftenreihe, 171 .

Gawron, T. (2008): Zentrale-Orte-System und Sicherung der Daseinsvorsorge in schrumpfenden Regionen: Zum Koordinationsdilemma zwischen Raumordnung und Fachplanung. Leipzig. = UFZ-Diskussionspapiere, 3/2008.

Hart, P.E.; Nilsson, N.J.; Raphael, B. (1968): A Formal Basis for the Heuristic Determination of Minimum Cost Paths. In: Transactions on Systems Science and Cybernetics 4, 2, 100-107.

Heiber, A. (2002): Erste öffentliche Ergebnisse. Wegezeiten pro Einsatz. http://www.syspra.de/fileadmin/PDF/Zeiterfassung \%20-\%20Bedeutung\%20\%20der\%20Wegezeit.pdf (Zugriff am 29.04.2016)

Heit, F.; Köppe, P.; Kratschke, M.; Reichenwallner, S. (2014): Herausforderungen für die Gesundheitsversorgung ländlicher Räume vor dem Hintergrund des demographischen Wandels. Das Fallbeispiel der durch Verwaltungsgrenzen zerschnittenen Fränkischen Schweiz. Erlangen, 131-150. = Mitteilungen der Fränkischen Geographischen Gesellschaft, 59.

Hemetsberger, M.; Ortner, S. (2008): Erreichbarkeitsbasierte Raster Raumanalyse - Anwendungen in der Landesplanung. In: Schrenk, M.; Popovich, V.; Engelke, D.; Elisei, P. (Hrsg.): Mobility Nodes as Innovation Hubs. Proceedings of 13. International Conference on Urban Planning, Regional Development and Information Society. Schwechat, 255-263.

Hielscher, V.; Nock, L.; Kirchen-Peters, S.; Blass, K. (2013): Zwischen Kosten, Zeit und Anspruch. Das alltägliche Dilemma sozialer Dienstleistungsarbeit. Wiesbaden.

Higgs, G.; White, S.D. (1997): Changes in service provision in rural areas. Part 1: The Use of GIS in Analysing Accessibility to Services in Rural Deprivation Research. In: Journal of Rural Studies $13,4,441-450$.

Jens, K. (2009): Wandel der Daseinsvorsorge - Von der Gleichwertigkeit der Lebensverhältnisse zur wirtschaftlichen, sozialen und territorialen Kohäsion. In: Neu, C. (Hrsg.): Daseinsvorsorge.
Eine gesellschaftswissenschaftliche Annäherung. Wiesbaden, 22-38.

Kaup, S.; Rieffel, P. (2013): Rasterbasierte Regionalstatistik. Dortmund. = ILS-Trends, $2 / 13$.

Küpper, P. (2011): Regionale Reaktionen auf den Demographischen Wandel in dünn besiedelten, peripheren Räumen. Berlin. = IÖR Schriften, 53.

Küpper, P.; Eberhardt, W. (2012): Nahversorgung in ländlichen Räumen. Endbericht. Johann Heinrich von Thünen-Institut, Institut für Ländliche Räume. Braunschweig (unveröffentlichtes Manuskript).

Küpper, P.; Steinführer, A.; Stelzenmüller, V.; Weingarten, P. (2013): Stellungnahme zum Entwurf der „Leitbilder und Handlungsstrategien für die Raumentwicklung in Deutschland 2013“. http://literatur.ti.bund.de/digbib_extern/dn053191.pdf (Zugriff am 26.04.2016).

Madelin, M.; Frasland, C.; Mathian, H.; Sanders, L.; Vincent, J.M. (2009): Das „MAUP“: Modifiable Areal Unit - Problem oder Fortschritt? In: Informationen zur Raumentwicklung 10, 645-660.

Neu C (2009): Daseinsvorsorge. Eine gesellschaftswissenschaftliche Annäherung. Wiesbaden.

Neumeier, S. (2012): Modellierung der Erreichbarkeit von Straßentankstellen. Untersuchung zum regionalen Versorgungsgrad mit Dienstleistungen der Grundversorgung. Braunschweig. = Arbeitsberichte aus der vTI-Agrarökonomie, 09/2012.

Neumeier, S. (2013): Modellierung der Erreichbarkeit öffentlicher Apotheken. Untersuchung zum regionalen Versorgungsgrad mit Dienstleistungen der Grundversorgung. Braunschweig. = Thünen Working Paper, 14.

Neumeier, S. (2014a): Modellierung der Erreichbarkeit von Supermärkten und Discountern. Untersuchung zum regionalen Versorgungsgrad mit Dienstleistungen der Grundversorgung. Braunschweig. $=$ Thünen Working Paper, 16.

Neumeier, S. (2014b): Open Source in accessibility analyses. Modelling of street petrol station accessibility in Germany. In: OSGEO Journal 13, 90-114.

Neumeier, S. (2015): Lokale Verteilung Ambulanter Pflegedienste nach SGB XI in Deutschland auf Basis eines rasterbasierten GIS-Erreichbarkeitsmodells. Braunschweig. = Thünen Working Paper, 47.

Schmitz-Veltin, A. (2006): Lebensbedingungen im demographischen Wandel. In: Raumforschung und Raumordnung 64, 5, 343-354.

Schulz, A.-C.; Bröcker, J. (2007): Die Erreichbarkeit der Arbeitsmärkte für Berufspendler aus den Gemeinden Schleswig-Holsteins. Kiel. $=\mathrm{IAB}$ regional, 01/2007.

Slupina, M.; Sütterlin, S.; Klingholz, R. (2015): Von Hürden und Helden. Wie sich das Leben auf dem Land neu erfinden lässt. Berlin.

Specht J.; Wenz K.; Häring, A.M.; Braun, C.L. (2013): Wandel im ländlichen Raum: Von Wandlungsprozessen zu neuen Kompetenzbedarfen. Eberswalde. http://hne.fh-eberswalde. de/_obj/D5F997CE-3EFB-41B1-9F52-423137259546/outline/ Wandel_im_laendlichen-Raum_Spechtetal_end.pdf (Zugriff am 26.04.2016)

Statistische Ämter des Bundes und der Länder (2010): Demographischer Wandel in Deutschland. Heft 2. Auswirkungen auf Krankenhausbehandlungen und Pflegebedürftige im Bund und in den Ländern, Ausgabe 2010. Wiesbaden.

Statistisches Bundesamt (2013a): Pflegestatistik 2011. Pflege im Rahmen der Pflegeversicherung 3. Bericht: Ländervergleiche - ambulante Pflegedienste. Wiesbaden.

Statistisches Bundesamt (2013b): Pflegestatistik 2011. Pflege im Rahmen der Pflegeversicherung. Deutschlandergebnisse. Wiesbaden.

Statistisches Bundesamt (2013c): Pflegestatistik 2011. Pflege im Rahmen der Pflegeversicherung 2. Bericht: Ländervergleiche Pflegebedürftige. Wiesbaden. 
Statistisches Bundesamt (2013d): Pflegestatistik 2011. Pflege im Rahmen der Pflegeversicherung. Kreisvergleich. Wiesbaden.

Steinführer, A. (2014): Anpassung an den demographischen Wandel - was heißt das eigentlich? In: Land-Berichte. Sozialwissenschaftliches Journal 17, 1, 9-25.

Steinführer, A.; Küpper, P.; Tautz, A. (2012): Gestaltung der Daseinsvorsorge in alternden und schrumpfenden Gemeinden - An- passungs- und Bewältigungsstrategien im Harz. Braunschweig. = Landbauforschung vTI agriculture and forestry research, Sonderheft, 367.

Steinführer, A.; Küpper, P.; Tautz, A. (2014): Adapt and cope: Strategies for safeguarding the quality of life in a shrinking ageing region. In: Comparative Population Studies 39, 2, 345-370. 